\title{
Precision Nutrient Rates and Placement in Conservation Maize-Wheat System: Effects on Crop Productivity, Profitability, Nutrient-Use Efficiency, and Environmental Footprints
}

\author{
Raj K. Jat ${ }^{1}$, Deepak Bijarniya ${ }^{2}$, Suresh K. Kakraliya ${ }^{3}$, Tek B. Sapkota ${ }^{4}{ }^{(}$, Manish Kakraliya ${ }^{3}$ (D) \\ and Mangi L. Jat ${ }^{2, *(D)}$ \\ 1 Borlaug Institute for South Asia (BISA), CIMMYT, Pusa 848125, Bihar, India; R.Jat@cgiar.org \\ 2 International Maize and Wheat Improvement Center, DPS Marg, NASC Complex, Pusa, \\ New Delhi 110012, India; d.bijarniya@cgiar.org \\ 3 ICAR-Central Soil Salinity Research Institute (CSSRI), Karnal 122001, Haryana, India; \\ kakraliyask@gmail.com (S.K.K.); manishkakraliya719@gmail.com (M.K.) \\ 4 International Maize and Wheat Improvement Center, Mexico City 56237, Mexico; t.sapkota@cgiar.org \\ * Correspondence: m.jat@cgiar.org
}

Citation: Jat, R.K.; Bijarniya, D.; Kakraliya, S.K.; Sapkota, T.B.; Kakraliya, M.; Jat, M.L. Precision Nutrient Rates and Placement in Conservation Maize-Wheat System Effects on Crop Productivity, Profitability, Nutrient-Use Efficiency, and Environmental Footprints. Agronomy 2021, 11, 2320. https:// doi.org/10.3390/agronomy11112320

Academic Editor: Maria Arlene Adviento-Borbe

Received: 17 October 2021 Accepted: 2 November 2021 Published: 17 November 2021

Publisher's Note: MDPI stays neutral with regard to jurisdictional claims in published maps and institutional affiliations.

Copyright: (c) 2021 by the authors Licensee MDPI, Basel, Switzerland. This article is an open access article distributed under the terms and conditions of the Creative Commons Attribution (CC BY) license (https:// creativecommons.org/licenses/by/ $4.0 /)$.
Abstract: Intensive tillage-based production systems coupled with inefficient fertilizer management practices have led to increased production costs, sub-optimal productivity, and significant environmental externalities. Conservation agriculture (CA) is being increasingly advocated as a management strategy to overcome these issues but precision nutrient management under the CA-based maizewheat system is rarely studied. Two year's (2014-2015 and 2015-2016) research was conducted at the research farm of BISA, Pusa, Bihar, India to develop precision nutrient management practices for CA-based management in the maize-wheat system. Seven treatment combinations involving (i) tillage (conventional tillage; CT \& permanent beds; PB) and (ii) nutrient management rates, application methods (farmers' fertilizer practices; FFP, state recommended dose of fertilizer; SR and precision nutrient management using Nutrient Expert tool; NE and GreenSeeker; (GS), applied using two methods; broadcasting (B) and drilling (D)) were investigated for multiple parameters. The results showed that NE, NE+GS, and SR-based nutrient management tactics with drilling improved crop yields, nutrient-use efficiency (NUE), and economic profitability relative to NE-broadcasting, SR broadcasting, and FFP broadcasting methods. Maize-wheat system productivity and net returns under NE+GS-drilling on PB were significantly higher by 31.2\%, 49.7\% compared to FFP-broadcasting method, respectively. Total global warming potential (GWP) was lower in the PB-based maize-wheat system coupled with precision nutrient management compared to CT-based maize-wheat system with FFP. Higher (15.2\%) carbon sustainability index (CSI) was recorded with NE-drilling compared to FFP-broadcasting method. Results suggests that PB-based maize-wheat system together with precision nutrient management approaches (NE+GS+drilling) can significantly increase crop yields, NUE, and profitability while reducing the emission of greenhouse gases (GHGs) from maize-wheat systems in eastern Indo Gangetic Plains (IGP).

Keywords: green seeker; site-specific nutrient management; tillage; residue management; greenhouse gas emission; climate change mitigation

\section{Introduction}

Maize-wheat (MW) system is the third most important cropping pattern in India, occupying about 2.0 million ha (Mha) primarily by smallholder farmers in stress-prone ecologies [1]. Maize-wheat system is generally followed in upland ecologies in smallholder eastern Indo-Gangetic Plains (IGP) of India, where maize is grown as rainfed crop during the rainy season (June to October), followed by wheat as an irrigated crop in the winter season (November to April). The major production constraints for rainy season maize 
are excess soil moisture and heavy infestation of weeds, which leads to significant yield losses and sometimes crop failure. Due to these risks during the rainy season, most of the farmers use open-pollinated varieties (OPVs) of maize only for household consumption purpose with suboptimal fertilizer nutrients and other management practices that result in low productivity [2]. In this maize-wheat system, wheat is planted by broadcasting the seed after repeated tillage operations with limited irrigation (1-2) and inappropriate fertilizer management. The average productivity of maize (rainy season) and wheat in the eastern IGP are 2.5 and $2.4 \mathrm{tha}^{-1}$, respectively [2], which is much lower (almost half) than that in western IGP. Eastern IGP is dominated by very small farm holding and the farmers have low investment capacity in farming and therefore grow crops with limited inputs including fertilizers. Fertilizer recommendations are mainly based on the response trials conducted without considering the nutrient supplying capacity of soil [3]. Given the higher government subsidy on urea than other fertilizers and lack of knowledge about balanced fertilizer application, farmers often apply nitrogen fertilizers, ignoring the sufficient application of other macros- and micro-nutrients [4]. Broadcast application of urea results in large losses of nutrients through volatilization and leaching thereby lowering the nutrient-use-efficiency and lower yield. Broadcasting of fertilizer nutrients can result in plant roots becoming surface feeders reducing nutrient uptake from deeper soil layers and unused $\mathrm{N}$ is then lost through leaching. Opportunities exist to improve NUE by adopting precision nutrient management techniques thus contributing to the sustainable intensification of cereal systems in eastern IGP [5]. NUE can be improved by the application of fertilizers at the right period, right rate, right place, and right source (based on $4 \mathrm{R}$ Nutrient Stewardship), and is an innovative approach for precise fertilization, a practice which is considered to be economical and is an environmentally sound fertilizer management technology, essential for long-term sustainability of maize-wheat system [6]. For example, drilling of nutrients facilitates roots to grow deeper to efficiently forage nutrients from the deeper soil layer which not only reduces the leaching losses and improves NUE but also reduces crop lodging. Applying nutrients in plant uptake-ready forms also ensures higher plant uptake. Similarly applying the right amount of fertilizer matching the plant nutrient demand will not only increase crop yield but also minimize the loss of nutrients through emission (particularly N2O) or leaching [3].

Conservation agriculture (CA) based on the principles of (i) minimum soil disturbance, (ii) soil covers with residue, and (iii) appropriate crop rotation, as resource conservation and sustainable production systems has been promoted. Conservation agriculture-based practices have the potential to reduce input costs and soil erosion, and improve crop and water productivity [1,7], resilience against climatic stress factors [5], and soil organic matter contents thus resulting in the improvement of soil biodiversity $[8,9]$. Conventional fertilizer recommendations, which have been calibrated mainly based on tillage-based systems, which are not fit for CA-based systems and precision nutrient management strategies must also be formulated taking into account the specific nutrient dynamics of CA-based systems. For example, crop residues retention on the soil surface as mulch under CA immobilizes some applied $\mathrm{N}$ during initial years but supplies further $\mathrm{N}$ through mineralization in later years and this needs to be factored into the nutrient management system. Broadcasting of $\mathrm{N}$ fertilizer in CA-based systems provides less soil-fertilizer contact due to surface mulch, which leads to more $\mathrm{N}$ volatilization losses as compared to conventional tillage system. Sub-surface drilling of $\mathrm{N}$ fertilizer either at planting time or in standing crop may reduce the volatilization losses and could improve the nutrient-use efficiency. This could be due to the differential availability of nutrient at the early stage of the growing period especially less mobile nutrient like $\mathrm{P}$ and $\mathrm{K}$ [10].

Several soil and plant-based methods, techniques and decision support tools have been developed, validated, and deployed for precision nutrient management in different crops [5,11]. For example, Green Seeker is a handheld sensor, which measures as normalized differences vegetative index (NDVI) and used for in-season $\mathrm{N}$ management in cereals $[12,13]$. NE decision support tool developed by International Plant Nutrition Institute (IPNI) in 
collaboration with International Maize and Wheat Improvement Center (CIMMYT) that can rapidly provide a nutrient recommendation without soil testing data for particular field plot [14]. As per our knowledge, no systematic research trials have been done for precision nutrient management tools and techniques including drilling of fertilizer nitrogen in the CA-based maize-wheat system. Therefore, this research trial was conducted to evaluate the effect of integrating (bundling) the 4R Nutrient Stewardship with CA-based agronomic practices on crop productivity, profitability, nutrient-use efficiency, and environmental footprints in maize-wheat rotation to inform researchers, farmers, and planners for formulating strategies toward a more sustainable farming future. The study was on a research field to test precision application (rate and placement) of nutrients in conservation agriculture-based cropping systems aimed to increase the input-use-efficiency, farm profit of smallholder farms in the region, and minimizing environmental foot prints.

\section{Materials and Methods}

\subsection{Study Site Characteristics}

On-station research trial was conducted for two years from 2014 to 2016 at Research Farm of Borlaug Institute for South Asia (BISA)-CIMMYT, Pusa, Samastipur, Bihar, India $(25.955705 \mathrm{~N}, 85.668865 \mathrm{E})$. This experiment was initiated from monsoon season 2014 with the portfolios of tillage, crop establishment, and fertilizer management practices in the maize-wheat system. The maize was grown during kharif season (rainy season) whereas succeeding wheat crop grown in rabi season (winter season). The soil texture of the experimental site is clay loam type with a medium range of organic matter content $(0.62 \%)$. The basic properties of the soil of experimental site are given in Table 1 . The climate of the experimental site is characterized by hot and humid summers and cold winters. The annual rainfall of the site is around $1344 \mathrm{~mm}$, most of which occur during the months of July, August, and September. Monthly rainfall, evaporation, minimum and maximum temperature, as well as sunshine hours during the study period were recorded from the weather station installed at the research site (Figure 1).

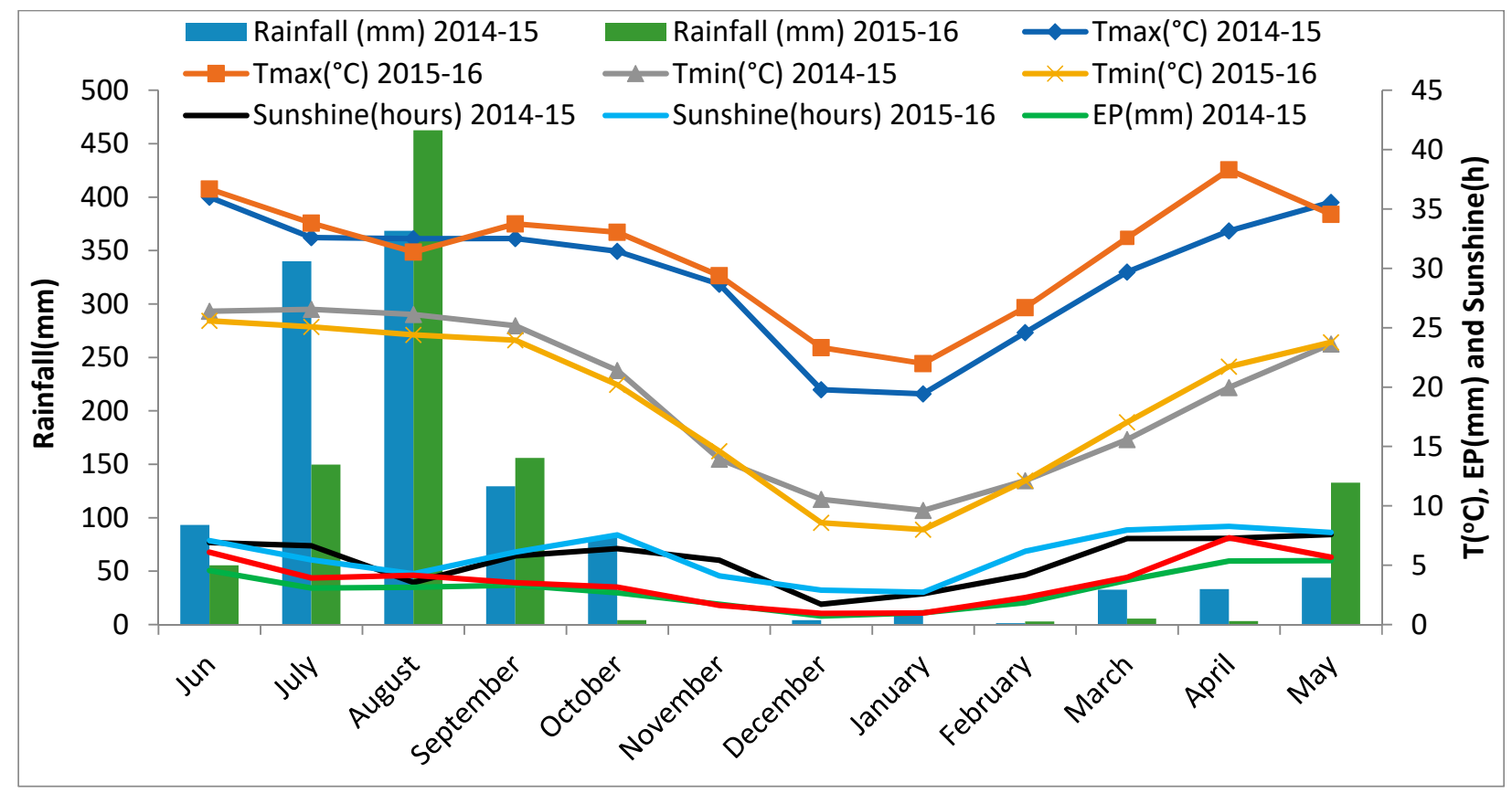

Figure 1. Monthly mean minimum and maximum temperatures $\left({ }^{\circ} \mathrm{C}\right)$, total rainfall $(\mathrm{mm})$, pan evaporation $(\mathrm{EP}, \mathrm{mm})$, and sunshine hours for the cropping calendars 2014-2015 and 2015-2016. 
Table 1. Basic initial soil properties and nutrient status $(0-15 \mathrm{~cm}$ depth) of the study site.

\begin{tabular}{cc}
\hline Soil Properties & Value \\
\hline Soil texture & Clay loam \\
$\mathrm{pH}(1: 2$ :: soil:water $)$ & 8.2 \\
$\left.\mathrm{EC}(\mathrm{dS} \mathrm{m})^{-1}\right)(1: 2::$ soil:water $)$ & 128.9 \\
Bulk Density; BD $\left(\mathrm{g} \mathrm{cm}^{-3}\right)$ & 1.6 \\
Organic carbon; OC $(\%)$ & 0.62 \\
Available N $\left(\mathrm{kg} \mathrm{ha}^{-1}\right)$ & 114 \\
Available P $\left(\mathrm{kg} \mathrm{ha}^{-1}\right)$ & 15 \\
Exchangeable $\mathrm{K}\left(\mathrm{kg} \mathrm{ha}^{-1}\right)$ & 61 \\
\hline
\end{tabular}

\subsection{Treatment Details and Experimental Design}

Seven treatments comprising of combinations of fertilizer application rates and fertilizer application methods (farmer's fertilizer practice (FFP) and drilling), tillage, and crop establishment methods (land preparation and planting methods) and crop residue management (Table 2) were tested in maize-wheat systems. FFP was identified based on survey of 50 farmers' of the area (Samastipur and Vaishali district of Bihar) and was 138:46:30 and 130:50:30 kg ha ${ }^{-1}$ of $\mathrm{N}: \mathrm{P}_{2} \mathrm{O}_{5}: \mathrm{K}_{2} \mathrm{O}$ for maize and wheat (2 years mean), respectively and applied by hand broadcast method. The ad-hoc state nutrient recommendation was based on the economic optima of nutrients for the state of Bihar by the Indian Council of Agricultural Research (ICAR). The state nutrient recommendations $\left(\mathrm{N}_{\mathrm{N}} \mathrm{P}_{2} \mathrm{O}_{5}: \mathrm{K}_{2} \mathrm{O}\right)$ were 160:60:40 and 150:60:40 $\mathrm{kg} \mathrm{ha}^{-1}$ for maize and wheat, respectively. Nutrient Expert ${ }^{\circledR}$ is an easy-to-use, interactive, and computer-based decision support tool that can rapidly provide nutrient recommendations for an individual farmer field in the presence or absence of soil testing data. Nutrient Expert ${ }^{\circledR}$ is based on Principles of Site-specific Nutrient Management. NE decision support tool, developed, calibrated, and validated by (IPNI) and (CIMMYT) was used for calculating the required dose of $\mathrm{N}, \mathrm{P}_{2} \mathrm{O}_{5}$, and $\mathrm{K}_{2} \mathrm{O}$ for maize and wheat crops at the study site. The nutrient doses calculations by NE were based on plant-specific demand of the nutrients for targeted crop yield. The NE-based recommendation was 143:50:53.5 and 136:45:63 kg ha ${ }^{-1}$ of $\mathrm{N}: \mathrm{P}_{2} \mathrm{O}_{5}: \mathrm{K}_{2} \mathrm{O}$ (average of in 2-years) for maize and wheat. In two out of seven treatment combinations, nitrogen management was further supplemented with a handheld optical sensor named GreenSeeker guided recommendation at 49 and 65 days after sowing in both the crops (Table 2). GreenSeeker is a handheld crop sensor that detects wavelengths of reflected light from the crop canopy and produces a normalized difference vegetation index value called NDVI that is correlated with leaf chlorophyll. Based on this information, side dress nitrogen rates that are aligned with site-specific crop needs can be prescribed. Based on the calculation, the full dose of $\mathrm{P}_{2} \mathrm{O}_{5}, \mathrm{~K}_{2} \mathrm{O}$ and $1 / 3 \mathrm{rd}$ dose of $\mathrm{N}$ was applied as basal (at planting time) and remaining 2/3rd the dose of $\mathrm{N}$ was applied in two/three splits according to different treatments as mentioned in Table 2 at the vegetative and tasseling stages in maize, and at the 1st, 2nd, and 3rd irrigation in wheat. In the treatments with drilling methods of application, fertilizer dose in both the crops was drilled using a double-disc bed planter having $67.5 \mathrm{~cm}$ distance between two discs (Figure 2) developed at CIMMYT-BISA, Pusa using narrow wheel fitted tractor to avoid the crop damage and in the broadcasting method the fertilizer application was done by hand. The fertilizer in wheat crop was drilled between the two rows of the wheat crop before 1st and 2nd irrigation at a depth of $5 \mathrm{~cm}$ using a disc planter. In the case of maize crop, the fertilizer was drilled at the center of the furrow nearby maize crop row at a depth of $5 \mathrm{~cm}$ using a disc bed planter. In all the treatments, $25 \mathrm{~kg} \mathrm{ha}^{-1} \mathrm{ZnSO}_{4}(21 \% \mathrm{Zn})$ was used once in a year before planting of maize. The experiment was carried out in the big size of plots $\left(1800 \mathrm{~m}^{2}\right)$. Completely a randomized block design was used and replicated thrice the time. 
Table 2. Treatment description (tillage, residue, nutrient rate, application methods and management strategies) in maize-wheat system.

\begin{tabular}{|c|c|c|c|c|c|c|c|c|c|c|}
\hline \multirow[t]{3}{*}{ Treatments } & \multirow[t]{3}{*}{ Nutrient Ratio } & \multirow[t]{3}{*}{$\begin{array}{l}\text { Application } \\
\text { Method }\end{array}$} & \multicolumn{4}{|c|}{ Residue Management } & \multicolumn{4}{|c|}{ NPK Rates * } \\
\hline & & & \multirow[t]{2}{*}{ Maize } & \multirow[t]{2}{*}{ Wheat } & \multicolumn{3}{|c|}{ Maize } & \multicolumn{3}{|c|}{ Wheat } \\
\hline & & & & & $\mathbf{N}$ & $\mathbf{P}_{2} \mathbf{O}_{5}$ & $\mathrm{~K}_{2} \mathrm{O}$ & $\mathbf{N}$ & $\mathbf{P}_{2} \mathrm{O}_{5}$ & $\mathrm{~K}_{2} \mathrm{O}$ \\
\hline $\begin{array}{l}\text { FFP-broadcast } \\
\text { (CT) }\end{array}$ & $30 \% \mathrm{~N}$ Total $\mathrm{P}$ and $\mathrm{K}$ Basal + Remaining $\mathrm{N}$ in 2 equal split & Broadcast & Removed & Removed & 138.0 & 46.0 & 30.0 & 130.0 & 50.0 & 30.0 \\
\hline $\begin{array}{l}\text { SR-broadcast } \\
(\mathrm{PB})\end{array}$ & $30 \% \mathrm{~N}$ Total $\mathrm{P}$ and $\mathrm{K}$ Basal+ Remaining in 3 equal split & Broadcast & $100 \%$ Retained & Anchored & 160.0 & 60.0 & 40.0 & 150.0 & 60.0 & 40.0 \\
\hline $\begin{array}{l}\text { SR-drilling } \\
\text { (PB) }\end{array}$ & $30 \% \mathrm{~N}$ Total $\mathrm{P}$ and $\mathrm{K}$ Basal+ Remaining in 3 equal split & Drilling & $100 \%$ Retained & Anchored & 160.0 & 60.0 & 40.0 & 150.0 & 60.0 & 40.0 \\
\hline $\begin{array}{l}\text { SR+GS-drilling } \\
(\mathrm{PB})\end{array}$ & $\begin{array}{l}30 \% \mathrm{~N} \text { Total P and K Basal remaining N in } 2 \text { splits, based } \\
\text { on GreenSeeker (GS) }\end{array}$ & Drilling & $100 \%$ Retained & Anchored & 157.7 & 60.0 & 40.0 & 149.9 & 60.0 & 40.0 \\
\hline $\begin{array}{l}\text { NE-broadcast } \\
\text { (PB) }\end{array}$ & $30 \% \mathrm{~N}$ Total P and K Basal+ Remaining in 3 equal split & Broadcast & $100 \%$ Retained & Anchored & 143.0 & 50.0 & 53.5 & 136.0 & 45.0 & 63.0 \\
\hline $\begin{array}{l}\text { NE-drilling } \\
(\mathrm{PB})\end{array}$ & $30 \% \mathrm{~N}$ Total $\mathrm{P}$ and K Basal+ Remaining in 3 equal split & Drilling & $100 \%$ Retained & Anchored & 143.0 & 50.0 & 53.5 & 136.0 & 45.0 & 63.0 \\
\hline $\begin{array}{l}\text { NE+GS-drilling } \\
\text { (PB) }\end{array}$ & $\begin{array}{l}30 \% \text { N Total P and K Basal- remaining N in } 2 \text { splits, split } \\
\text { based on (GS) }\end{array}$ & Drilling & $100 \%$ Retained & Anchored & 155.5 & 50.0 & 53.5 & 142.1 & 45.0 & 63.0 \\
\hline
\end{tabular}

$\mathrm{CT}=$ conventional tillage; $\mathrm{PB}=$ permanent bed; $\mathrm{FFP}=$ farmers fertilizer practices; $\mathrm{SR}=$ state recommendation; $\mathrm{GS}=$ GreenSeeker based; NE $=$ nutrient expert ${ }^{\circledR}$ based. ${ }^{*}$ Average of two years. 


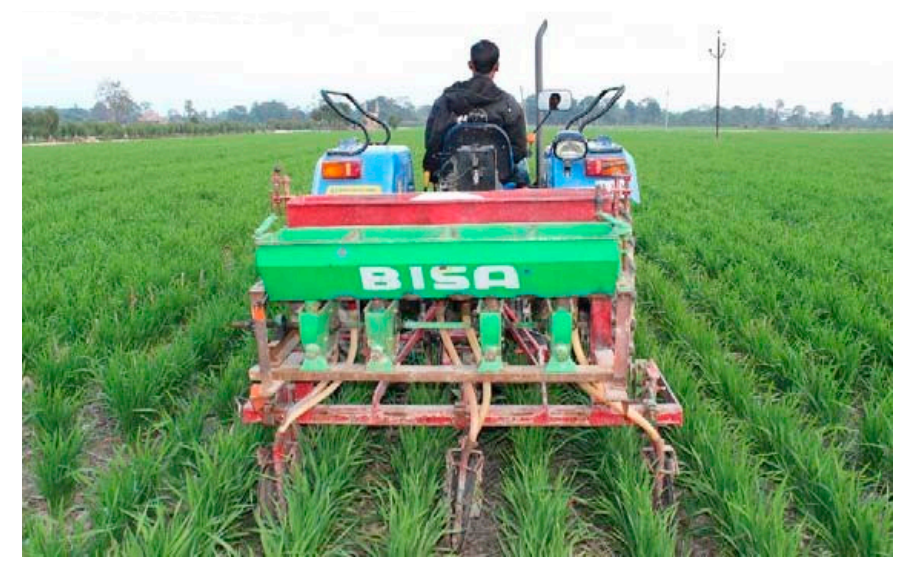

Figure 2. Disc bed planter developed at CIMMYT-BISA farm, Bihar.

\subsection{Crop Management}

\subsubsection{Tillage, Crop Establishment, and Weed Management}

The site was under a continuous rice-wheat system prior to this study. Before establishment of the experimental crop, the field was ploughed using disc plough to break hard pan if any. Thereafter, it was pulverized at the optimum moisture level (field capacity) with a cultivator and then levelled using a laser-assisted precision land levelling system attached with a 60- horsepower (hp) 4-wheel tractor.

The conventional tillage (CT) involved ploughing one each with disc harrow followed by a spring-tine cultivator before sowing each crop. Maize was planted on fresh raised beds in the first year however, in consequent seasons they were kept as permanent beds (PB). The width of the beds was $67 \mathrm{~cm}$ (mid-furrow to mid furrow), with $37 \mathrm{~cm}$ wide flat top, and $15 \mathrm{~cm}$ furrow depth. Bed shaper was used for reshaping of the beds at the end of every cropping cycle. Maize hybrid DKC-9144 was seeded with a seed rate of $20 \mathrm{~kg} \mathrm{ha}^{-1}$ in third week of June every year. One row of maize was planted in the center of each bed with a plant-to-plant distance of $20 \mathrm{~cm}$ and row to row distance of $67.5 \mathrm{~cm}$. Wheat cultivar, HD2967 was sown in the first week of November with a seed rate of 82.5 and $100 \mathrm{~kg} \mathrm{ha}^{-1}$ in PB and CT plots, respectively. In PB plots, two rows of wheat were planted using crop bed planter on each side of the beds with a row-to-row distance of $30 \mathrm{~cm}$. Prior to sowing, maize and wheat seeds were treated with imidachloropid and tabuconazole @5 mL kg $\mathrm{m}^{-1}$ and $1 \mathrm{~g} \mathrm{~kg}^{-1}$ seed, respectively. In PB no tillage plots, weeds before sowing of maize and wheat were killed using glyphosate @ $900 \mathrm{~g}$ a.i. ha ${ }^{-1}$. To prevent weed germination in maize, pre-emergence spray of Atrazine (Atrataf 50 WP) @1.5 kg a.i. ha ${ }^{-1}$ was done on next day of sowing and Laudis (Tembotrione $34.4 \%$ SC @120 a.i. ha ${ }^{-1}$ ) applied after 30-35 days. For wheat, tank mix solution of sulfosulfuron+metsulfuron @ 30+2 $\mathrm{g}$ a.i. ha ${ }^{-1}$ or clodinafop- ethyl+metsulfuron @ 60+4 $\mathrm{g}$ a.i. ha ${ }^{-1}$ at 30 days after sowing was applied to control grassy as well as broad leaf weeds. For controlling of fall armyworm and borer in maize, emamectin benzoate 5\% SG (Missile) @ $250 \mathrm{~g} /$ ha or chlorantraniliprole 18.5\% SC (Coargen) $160 \mathrm{~mL} /$ ha were applied when insect pests appear.

There were three residue management practices; full residue retention means all residue of the crop kept in the plot, anchored residue means 6 inches of standing residue kept in plot, and residue removal means all residue removed from the plot.

\subsubsection{Water Management}

A 15-cm polyvinyl chloride (PVC) pipeline was installed in a 90-cm-deep trench with an outlet on one corner of the experimental field for precise water application. The PVC pipeline was connected to a tube well. In maize crop one irrigation was applied during the longer dry spell in rainy season. Wheat crop was planted on residual soil moisture after harvesting of maize. Three (3) post sown irrigations were applied to wheat at 20-25, 40-45, and 65-70 days after seeding using 6-7 $\mathrm{cm}$ water depth. 


\subsection{Data Recording}

Crop management data (input-output) were recorded for each crop under every treatment using standard data recording protocols for computation of production economics. In case of maize, the number of cobs per meter square, grains per cob, and 100-grain weight and in case of wheat the number of effective tillers per meter square, grains per spike, and 1000-grain weight were noted in respective years. Net area harvested for recoding grain and straw yields in the middle of plots was $9 \mathrm{~m}^{2}$ and $10.8 \mathrm{~m}^{2}$ in CT and PB plots of both crops, respectively. Grain yield of wheat and maize were noted at $14 \%$ moisture content basis. To explain the overall effect of treatments on crop productivity, the yield of non-wheat crops (maize) was converted into wheat equivalent yield (WEY) $\left(\mathrm{t} \mathrm{ha}^{-1}\right)$ and calculated using the following equation:

WEY $\left(\mathrm{t} \mathrm{ha}^{-1}\right)=\left[\left\{\right.\right.$ Maize yield $\left(\mathrm{t} \mathrm{ha}^{-1}\right) \times$ MSP of Maize $\left.\left(\operatorname{INR} \mathrm{t}^{-1}\right)\right\} /$ MSP of Wheat $\left.\left(\mathrm{INR} \mathrm{t}^{-1}\right)\right]$ where; $\mathrm{WEY}=$ wheat equivalent yield, $\mathrm{MSP}=$ minimum support price, $\mathrm{INR}=$ Indian Rupees .

\subsection{Economic Analysis}

The variable cost of production comprised human labor, machinery use, and inputs such as tillage operations, planting, seed, irrigation, fertilizer, pesticides, harvesting, and threshing. Man-days per hectare basis was used to calculate cost of human labor used for different input operations (seeding to harvesting). The time (h) recorded to complete each field operation in each treatment was noted and expressed as person-days per hectare $(8 \mathrm{~h}$ to be equivalent to 1 person-day). The cost of labor was computed according to minimum wage rate as per the Indian Labor Law. Similarly, total time (h) consumed by a tractor in different field operations such as tillage, seeding, and harvesting was recorded and expressed as hours per hectare. The cost per unit time of machinery/equipment used was based on the standard custom hired rates prevailed in the region to perform the different farm operations. The irrigation cost was calculated from diesel consumption required for irrigating the field multiplied with current market price of diesel plus the price of labor used in irrigation application. The total variable cost (TVC) of production was obtained by summed up all input costs. The grain and straw yield of each crop multiplied with market prices of the product was used to calculate the gross returns (GR) (Table 3). The net returns (NR) were calculated by using the following equation: NR = GR - TVC. The benefit: cost $(B: C)$ ratio calculated by dividing the TVC in NR: B:C ratio $=N R / T V C$. All the economic data were converted into US\$ using average exchange rate of respective years (Table 3 ).

Table 3. Values of key inputs and outputs used for economic analysis in 2014-2015 and 2015-2016.

\begin{tabular}{|c|c|c|}
\hline \multirow[t]{2}{*}{ Item/Commodity } & \multicolumn{2}{|c|}{ Values (INR) } \\
\hline & 2014-2015 & 2015-2016 \\
\hline Maize grain $\left(\mathrm{kg}^{-1}\right)$ & 12.5 & 13.0 \\
\hline Maize residue $\left(\mathrm{ha}^{-1}\right)$ & 1.05 & 1.05 \\
\hline Maize seed $\left(\mathrm{kg}^{-1}\right)$ & 200 & 200 \\
\hline Wheat grain $\left(\mathrm{kg}^{-1}\right)$ & 14.0 & 15.0 \\
\hline Wheat residue $\left(\mathrm{kg}^{-1}\right)$ & 2.3 & 2.3 \\
\hline Wheat seed $\left(\mathrm{kg}^{-1}\right)$ & 25 & 25 \\
\hline Urea $\left(\mathrm{kg}^{-1}\right)$ & 5.8 & 5.8 \\
\hline Di-ammonium-phosphate $\left(\mathrm{kg}^{-1}\right)$ & 23 & 23 \\
\hline Muriate of potash $\left(\mathrm{kg}^{-1}\right)$ & 16.2 & 16.2 \\
\hline Zinc sulphate; $\left(\mathrm{kg}^{-1}\right)$ & 40 & 40 \\
\hline Harrowing $\left(\mathrm{ha}^{-1}\right)$ & 1500 & 1500 \\
\hline Cultivator $\left(\mathrm{ha}^{-1}\right)$ & 1000 & 1000 \\
\hline Planking $\left(\mathrm{ha}^{-1}\right)$ & 450 & 450 \\
\hline Bed planter $\left(\mathrm{ha}^{-1}\right)$ & 850 & 850 \\
\hline Seed drill $\left(\right.$ ha $\left.^{-1}\right)$ & 1000 & 1000 \\
\hline Minimum support price (MSP) for maize $\left(\mathrm{kg}^{-1}\right)$ & 13.25 & 13.65 \\
\hline Minimum support price (MSP) for wheat $\left(\mathrm{kg}^{-1}\right)$ & 14.5 & 15.25 \\
\hline Wages Rate $\left(\right.$ person $^{-1}$ day $^{-1}$ ) & 193 & 204 \\
\hline USD (\$) to INR Conversation rate & 62 & 66 \\
\hline
\end{tabular}




\subsection{Global Warming Potential (GWP)}

Mitigation options tool (MOT) were used to estimate greenhouse gases (GHGs) emissions for maize-wheat system [15]. This tool was developed by Climate Change, Agriculture and Food Security (CCAFS) in collaboration with the University of Aberdeen [15]. Basically, MOT estimates the performance of production system on the basis of emission of GHG perspective both in terms of land-use efficiency and efficiency per unit of product from different inputs used in each crop [15]. To estimate the GWP, all GHGs emitted from production systems are converted into $\mathrm{CO}_{2}$-equivalents $\left(\mathrm{CO}_{2}\right.$-eq) using the global warming potential (over 100 years) of 34 and 298 for $\mathrm{CH}_{4}$ and $\mathrm{N}_{2} \mathrm{O}$, respectively [16]. Yield-scaled GWP/GHG intensity of each crop was computed by dividing the total GWP by grain yield.

GWP $\left(\mathrm{kg} \mathrm{CO}_{2}\right.$-eq. ha $\left.{ }^{-1}\right)=\left[\left\{\mathrm{CO}_{2}\left(\mathrm{~kg} \mathrm{ha}^{-1}\right)+\mathrm{N}_{2} \mathrm{O}\left(\mathrm{kg} \mathrm{ha}^{-1}\right)\right\} \times\left\{298+\mathrm{CH}_{4}\left(\mathrm{~kg} \mathrm{ha}^{-1}\right) \times 34\right\}\right.$

\subsection{Total Carbon Input and Output}

The carbon equivalence as suggested by Lal and Kimble [17] for different production inputs such as inorganic fertilizers, diesel in tillage operations, lubricants, machinery, and pesticides etc., was used for the assessment of total carbon inputs and expressed in $\mathrm{MJ} \mathrm{ha}^{-1}$. Grain yield, straw yield, and root biomass parameters of $C$ output were included for conversion in carbon equivalent.

\subsection{Carbon Sustainability Index (CSI)}

CSI for both the years was determined by dividing the difference between the total C output and C input by $\mathrm{C}$ input (Lal 2005).

$$
\mathrm{CSI}=\{(\mathrm{Co}-\mathrm{Ci}) / \mathrm{Ci}\}
$$

where CSI—carbon sustainability index, $\mathrm{Co} —$ carbon output, $\mathrm{Ci}-$ carbon input.

\subsection{Statistical Analysis}

The analysis of variance (ANOVA) technique was used for analysis of different parameters [18]. Data analysis was done by using SAS 9.1 software (V 9.1, Carry, NC, USA) [19]. The individual and interactive effects of tillage treatment (i.e., tillage), fertilizer management, fertilizer application methods on crop yields and GHGs emission were analyzed with the SAS software. When the Fisher-test was significant, a least significant difference test $(p \leq 0.05)$ was used to separate the means. Yield benefit of fertilizer management and application methods was calculated as the grain yield differences between CA (conservation agriculture) and the conventional practice (FP). Relative yield of fertilizer management and application methods in CA and FP was also plotted for each cropping sequence and the advantage of each treatment was evaluated. Contrast study and correlation matrix was done with JMP 14.1 software.

\section{Results}

\subsection{Weather during the Study Period}

There was a statistical difference in the amount of rainfall during the two wheat seasons. 2014-2015 wheat season (November to mid-April) received more rainfall $(79.6 \mathrm{~mm})$ than the same period in 2015-2016 (11.6 mm). In the first year, a significant amount of total wheat season rainfall occurred during March and April which affected crop production. Kharif season (June to October) in 2014 and 2015 received 1012.3 and $827.4 \mathrm{~mm}$ of rainfall, respectively. However, during kharif season of 2014, a significant amount of total rainfall was received in the months of August and September. In 2015, kharif season, maximum rainfall was received in the month of August. Monthly mean daily evaporation (EP) was higher in 2015 compared to 2014 in both the seasons. Similarly, monthly mean daily maximum, minimum temperature, and sunshine hours were similar for most of the growing season in both the years (Figure 1). 


\subsection{Crop Productivity}

\subsubsection{Maize}

The treatments under investigation significantly differed in the productivity of maize during both years of the experimentation. It was observed that treatments having nutrient drilling component recorded a higher yield than the treatments having nutrient broadcast component. The highest maize yield was observed in the treatment NE+GS-drilling (PB) which was significantly at par with NE-drilling (PB), SR+GS-drilling (PB), and SR-drilling (PB). The treatment NE+GS-drilling (PB) recorded a higher yield of $36.7 \%$ and $47.24 \%$ during 2014 and 2015, respectively, over FFP-broadcast (CT) treatment compared with the CA treatments. NE+GS-drilling $(\mathrm{PB})$ recorded the higher maize yield $17.8 \%$ and $19.7 \%$ during 2014 and 2015, respectively over SR-broadcast (PB). The fertilizer application methods significantly influenced the productivity of kharif maize. Drilling of state recommended fertilizers in CA $\{$ SR-drilling (PB) \} increased about $10 \%$ maize yield over broadcasting of the same amount of fertilizer \{SR-broadcast (PB)\} in PB. Drilling of NE+GS-guided nutrient increased maize yield by 11.0 and $12.7 \%$ in 2014 and 2015, respectively, over the broadcasting of the same amount of fertilizer in the same planting system (i.e., $\mathrm{PB}$ ). The treatment SR-drilling (PB) recorded $27.1 \%$ and $9.5 \%$ higher yield during 2014 and $35.2 \%$ and $9.9 \%$ higher yield during 2015 compared to those recorded for FFP-broadcast (CT) and SR-broadcast (PB), respectively (Table 4). The contrast effects (Broadcast vs. Drilling, FFP vs. site specific nutrient management (SSNM), FFP-broadcast (B) vs. SR-broadcast, FFP-B vs. SR-drilling, FFP-B vs. SR+GS-drilling, FFP-B vs. NE-broadcast, FFP-B vs. NEdrilling, FFP-B vs. NE+GS-drilling) were significant to maize crop productivity in both the years (Table S1).

\subsubsection{Wheat}

Wheat grain yield was significantly influenced by different fertilizer rates and application methods in both years (Table 4). NE+GS-drilling (PB), NE-drilling (PB), SR+GS-drilling (PB), SR-drilling (PB) recorded 23.4, 21.6, 17.1, and 16.9\% (during the first year) and 20.8, $19.5,18.6$, and $16.5 \%$ (during the second year) higher yield compared to that of FFPbroadcast (CT), respectively. NE-drilling (PB) and SR-drilling (PB) recorded 10.2 and 5.9\% higher yield in 2014-2015 and 12.4, 9.6\% in 2015-2016 compared to SR-broadcast (PB), respectively. On average, drilling in CA-based (PB) system yielded $19.3 \%$ higher wheat yield (mean of two years) compared to farmer's fertilizer rate with broadcasting application $\{$ FFP-broadcast (CT)\}. The contrast effects (Broadcast vs. Drilling, FFP vs. SSNM, FFP-B vs. NE-drilling, FFP-B vs. NE+GS-drilling) were significant, whereas FFP-broadcast (B) vs. SR-broadcast, FFP-B vs. SR-drilling, FFP-B vs. SR+GS-drilling, FFP-B vs. NE-broadcast were non-significant to wheat crop productivity in 2014-2015. In 2015-2016, FFP-broadcast (B) vs. SR-broadcast and FFP-B vs. NE-broadcast were found non-significant whereas rest of the treatments contrast were found significant (Table S1).

\subsubsection{Maize-Wheat System}

Higher maize-wheat system (wheat equivalents) productivity was recorded with the drilling of the fertilizer $\mathrm{N}$ rates guided by NE+GS in PB system compared to conventional tillage with the broadcasting of $\mathrm{N}$ fertilizer in both years. Maize-wheat system productivity was increased by 21.7-29.8\% during 2014-2015 and 24.8-32.5\% during 2015-2016 in PB with precision nutrient rates and drilling (NE+GS-drilling (PB), NE-drilling (PB), NE-broadcast (PB), SR+GS-drilling (PB), SR-drilling (PB) compared to FFP-broadcast (CT) application (Table 4, Figure 3). NE+GS-drilling (PB) recorded 14.8 and $16.6 \%$ higher yield during the first and second years, respectively over SR-broadcast (PB)). NE+drilling (PB) increased the maize-wheat system productivity by $10.0 \%$ (2 years' mean) compared to NE-broadcast (PB). Similarly, SR-drilling (PB) increased maize-wheat system productivity by $8.7 \%$ (2 years mean) compared to SR-broadcast (PB). The Box and normal quantile plots show the results of the normal distribution of maize-wheat system grain yield (A) and maize-wheat system biomass yield (B) (Figure 3). The values of each treatment normally distributed within 
the replication were calculated from cumulative probability values. The contrast effects (Broadcast vs. Drilling, FFP vs. SSNM, FFP-broadcast (B) vs. SR-broadcast, FFP-B vs. SR-drilling, FFP-B vs. SR+GS-drilling, FFP-B vs. NE-broadcast, FFP-B vs. NE-drilling, FFP-B vs. NE+GS-drilling) were significant to maize-wheat system crop productivity in both the years (Table S1).

Table 4. Significance of effects of nutrient managements (NM) and application methods on grain yield, net return, and B: C ratio as resulting from analysis of variance (ANOVA) during year 2014-2015 and 2015-2016 in maize-wheat system.

\begin{tabular}{|c|c|c|c|c|c|c|c|c|c|}
\hline \multirow[t]{2}{*}{ Treatments $^{a}$} & \multicolumn{3}{|c|}{ Grain Yield (t/ha) } & \multicolumn{3}{|c|}{ Net Return (USD/ha) } & \multicolumn{3}{|c|}{ B:C Ratio } \\
\hline & Maize & Wheat & System & Maize & Wheat & System & Maize & Wheat & System \\
\hline \multicolumn{10}{|l|}{ 2014-2015 } \\
\hline FFP-broadcast (CT) & $4.36^{\mathrm{Db}}$ & $4.43^{\mathrm{C}}$ & $8.68^{\mathrm{E}}$ & $441^{\mathrm{D}}$ & $715^{\mathrm{D}}$ & $1156^{\mathrm{E}}$ & $0.88^{\mathrm{E}}$ & $1.27^{\mathrm{D}}$ & $1.09^{\mathrm{D}}$ \\
\hline SR-broadcast $(\mathrm{PB})$ & $5.06^{\mathrm{C}}$ & $4.89^{\mathrm{B}}$ & $9.81^{\mathrm{D}}$ & $578^{C}$ & $855^{C}$ & $1433^{\mathrm{D}}$ & $1.12^{\mathrm{D}}$ & $1.58^{\mathrm{C}}$ & $1.35^{\mathrm{C}}$ \\
\hline SR-drilling (PB) & $5.54 \mathrm{AB}$ & $5.18^{\mathrm{AB}}$ & $10.58^{\mathrm{BC}}$ & $662 \mathrm{AB}$ & $910 \mathrm{ABC}$ & $1572^{\mathrm{C}}$ & $1.23^{\mathrm{BC}}$ & $1.61^{\mathrm{C}}$ & $1.43^{\mathrm{BC}}$ \\
\hline SR+GS-drilling $(\mathrm{PB})$ & $5.59 \mathrm{AB}$ & $5.19 \mathrm{AB}$ & $10.64^{\mathrm{BC}}$ & $670 \mathrm{AB}$ & $914 \mathrm{ABC}$ & $1585^{\mathrm{BC}}$ & $1.25^{\mathrm{ABC}}$ & $1.61^{\mathrm{BC}}$ & $1.43^{\mathrm{B}}$ \\
\hline NE-broadcast (PB) & $5.37^{\mathrm{BC}}$ & $4.96^{\mathrm{B}}$ & $10.20 \mathrm{CD}$ & $639^{\mathrm{BC}}$ & $888^{B C}$ & $1528 \mathrm{CD}$ & $1.22 \mathrm{CD}$ & $1.65^{\mathrm{ABC}}$ & $1.44^{\mathrm{B}}$ \\
\hline NE-drilling $(\mathrm{PB})$ & $5.91^{\mathrm{A}}$ & $5.39^{\mathrm{A}}$ & $11.14 \mathrm{AB}$ & $731^{\mathrm{A}}$ & $963^{\mathrm{AB}}$ & $1695 \mathrm{AB}$ & $1.34 \mathrm{~A}$ & $1.70 \mathrm{AB}$ & $1.52^{\mathrm{A}}$ \\
\hline $\mathrm{NE}+\mathrm{GS}$-drilling $(\mathrm{PB})$ & $5.96^{\mathrm{A}}$ & $5.47^{\mathrm{A}}$ & $11.28^{\mathrm{A}}$ & $736^{\mathrm{A}}$ & $981^{\mathrm{A}}$ & $1717^{\mathrm{A}}$ & $1.33^{\mathrm{AB}}$ & $1.71^{\mathrm{A}}$ & $1.52 \mathrm{~A}$ \\
\hline \multicolumn{10}{|l|}{ 2015-2016 } \\
\hline FFP-broadcast (CT) & $4.09^{\mathrm{E}}$ & $4.60^{\mathrm{C}}$ & $8.56^{\mathrm{E}}$ & $388^{\mathrm{D}}$ & $737^{\mathrm{D}}$ & $1125^{\mathrm{D}}$ & $0.83^{\mathrm{D}}$ & $1.29^{\mathrm{C}}$ & $1.08^{\mathrm{D}}$ \\
\hline SR-broadcast (PB) & $5.03^{\mathrm{D}}$ & $4.89^{\mathrm{C}}$ & $9.76^{\mathrm{D}}$ & $562^{C}$ & $833^{C}$ & $1396^{C}$ & $1.14^{\mathrm{C}}$ & $1.54^{\mathrm{B}}$ & $1.35^{\mathrm{C}}$ \\
\hline SR-drilling (PB) & $5.53^{\mathrm{BC}}$ & $5.36^{\mathrm{AB}}$ & $10.72^{\mathrm{BC}}$ & $645^{\mathrm{B}}$ & $932 \mathrm{AB}$ & $1578^{\mathrm{AB}}$ & $1.26^{\mathrm{B}}$ & $1.63^{\mathrm{AB}}$ & $1.45^{\mathrm{B}}$ \\
\hline SR+GS-drilling (PB) & $5.54^{\mathrm{BC}}$ & $5.46^{\mathrm{A}}$ & $10.83 \mathrm{AB}$ & $648^{\mathrm{B}}$ & $950^{\mathrm{A}}$ & 1599 A & $1.27^{\mathrm{B}}$ & $1.65^{\mathrm{A}}$ & $1.47^{\mathrm{AB}}$ \\
\hline NE-broadcast (PB) & $5.34 \mathrm{CD}$ & $4.96^{\mathrm{BC}}$ & $10.14^{\mathrm{CD}}$ & $625^{\mathrm{BC}}$ & $851^{\mathrm{BC}}$ & $1477^{\mathrm{BC}}$ & $1.26^{\mathrm{B}}$ & $1.58^{\mathrm{AB}}$ & $1.43^{\mathrm{BC}}$ \\
\hline NE-drilling $(\mathrm{PB})$ & $5.93 \mathrm{AB}$ & $5.50^{\mathrm{A}}$ & $11.24 \mathrm{AB}$ & $724^{\mathrm{A}}$ & $951^{\mathrm{A}}$ & $1675^{\mathrm{A}}$ & $1.40^{\mathrm{A}}$ & $1.66^{\mathrm{A}}$ & $1.54^{\mathrm{A}}$ \\
\hline $\mathrm{NE}+\mathrm{GS}$-drilling $(\mathrm{PB})$ & $6.02^{\mathrm{A}}$ & $5.56^{\mathrm{A}}$ & $11.39^{\mathrm{A}}$ & $733^{A}$ & $966^{\mathrm{A}}$ & $1699^{\mathrm{A}}$ & $1.39^{\mathrm{A}}$ & $1.67^{\mathrm{A}}$ & $1.54^{\mathrm{A}}$ \\
\hline
\end{tabular}

${ }^{a}$ Refer Table 2 for details of nutrient management treatments. ${ }^{\mathrm{b}}$ Within year, crops and cropping system, means under different nutrient management strategies bearing different letters are significantly different from one another based on LSD 0.05 .

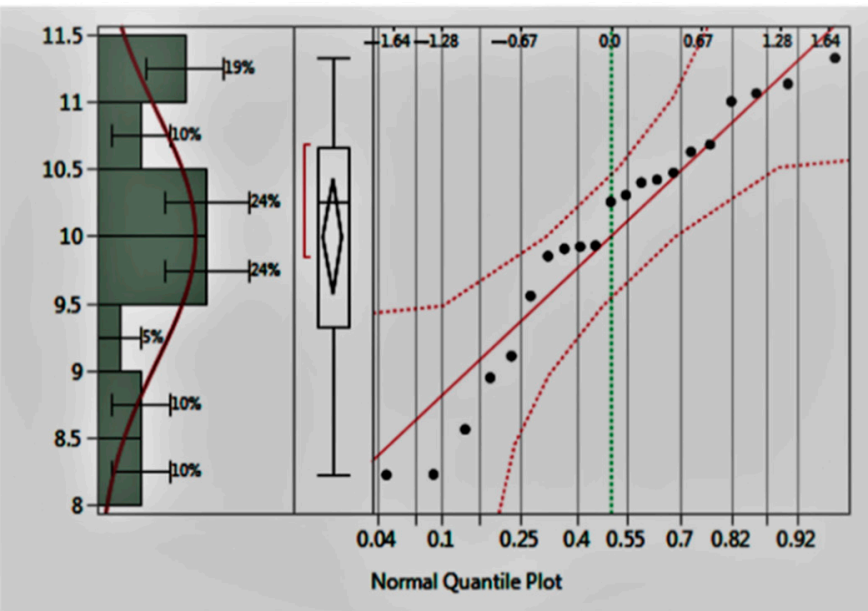

(A)

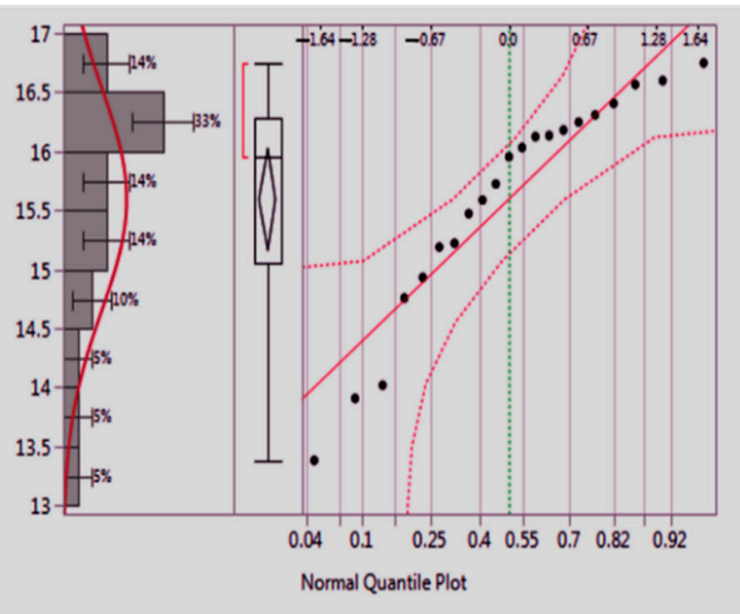

(B)

Figure 3. The Box and normal quantile plot showing results of normal distribution of maize-wheat system grain yield (A) and maize-wheat system biomass yield (B). The $y$-axis shows the maize-wheat system grain yield and biomass yield. The upper $x$-axis shows the normal quantile scale, lower $x$-axis shows the empirical cumulative probability for each value, and dashed red line shows the Lilliefors confidence bounds.

\subsection{Economic Profitability}

Higher cost of cultivation and lowest benefit: cost (B:C) ratio was recorded under FFP (CT) treatment compared to the rest of the remaining treatment during both years of the field trial (Table 4). The differences in cost of cultivation in PB broadcasting and PB-drilling were primarily due to the additional cost of drilling. The treatments, SR+GS+drilling (PB), 
$\mathrm{NE}+$ drilling $(\mathrm{PB})$, and NE+GS+drilling $(\mathrm{PB})$ had statistically higher net returns over the FFP-broadcast (CT) treatment in both the seasons of the experiment. The net return of maize, wheat, and MW system, was in the order of NE+GS-drilling (PB) > NE-drilling (PB) $>$ SR+GS-drilling $(\mathrm{PB})>$ SR-drilling $(\mathrm{PB})>$ NE-broadcast $(\mathrm{PB})>$ SR-broadcast $(\mathrm{PB})>$ FFPbroadcast (CT) during both the years (Table 4, Figure 4). The treatment NE+GS-drilling (PB) recorded 48.5 and $50.8 \%$ higher net returns (2 years mean) in maize and wheat, respectively over the FFP-broadcast (CT) treatment. The average net returns (2 yrs' mean) were 23.0-50.8\% higher with the treatment having nutrient drilling as compared to FFP-broadcast (CT). The highest net return (2-year mean) was recorded in the treatment NE+GS-drilling (PB) which was $0.9,16.2,11.4,12.4$, and $28.8 \%$ higher in maize and 1.7, 11.9, 4.4, 5.7, and $15.3 \%$ higher in wheat as compared to the treatments NE-drilling (PB), NE-broadcast (PB), SR+GS-drilling (PB), SR-drilling (PB), and SR-broadcast (PB), respectively. The contrast effects (Broadcast vs. Drilling, FFP vs. SSNM, FFP-B vs. SR-drilling, FFP-B vs. SR+GSdrilling, FFP-B vs. NE-broadcast, FFP-B vs. NE-drilling, FFP-B vs. NE+GS-drilling) were significant to economic profitability in both years. Although FFP-broadcast (B) vs. SR-broadcast was found non-significant in the year of 2014-2015) (Table S1).

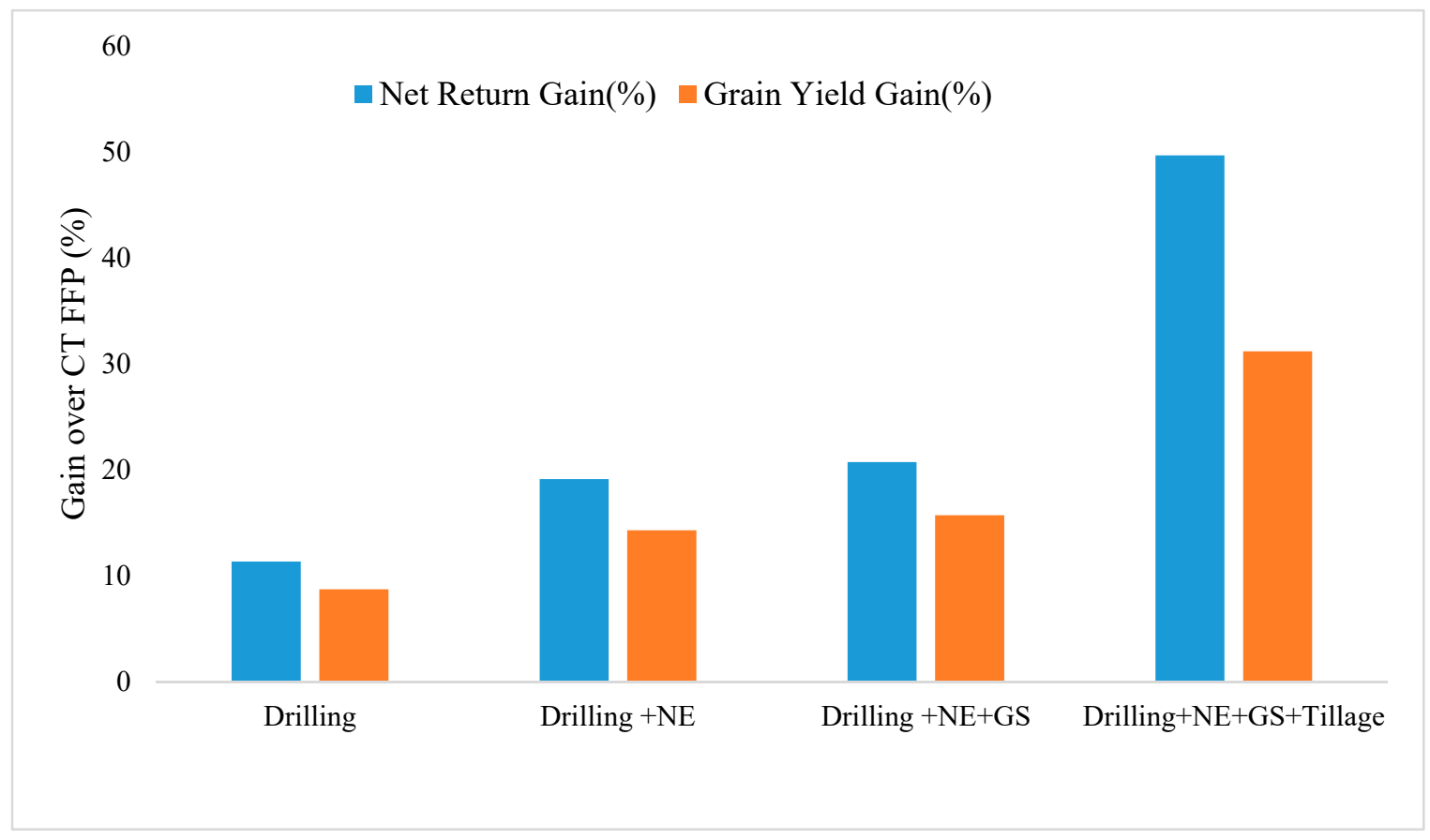

Figure 4. Bar diagram representing the effect of various nutrient management methods and practices on productivity and profitability in maize-wheat system.

\subsection{Nutrient-Use Efficiency (NUE)}

The NUE was expressed as partial factor productivity (PFP) of applied N, P, and K though varied statistically among different rates of nutrient applications nutrient management rates/strategies but not within the same application method. The averaged PFP of $\mathrm{N}$ of both the years was higher in NE-drilling (PB) compared to FFP-broadcast (CT) (Figure 5). The application of $\mathrm{P}$ on the basis of NE, recorded higher PFP compared to the applications on the basis of state recommendation and the farmer's practice. PFP of N based on NE was significantly different from farmers' practice but not from that of state recommendation drilling and GreenSeeker (GS)-based rates under all fertilizer application methods in both the cropping cycle (Figure 5). Higher K-use efficiency was observed with FFP-broadcast (CT) as compared to other methods of application in both the years. PFP of $\mathrm{K}$ based on NE, GS based and State Recommendation with drilling method (NE-drilling (PB), NE+GS-drilling (PB), and SR-drilling (PB) was higher than the broadcasting method of application (NE-broadcast (PB) and SR-broadcast (PB) in both the study years. Linear 
contrast (Broadcast vs. Drilling, FFP vs. SSNM, FFP-broadcast (B) vs. SR-broadcast, FFP-B vs. SR-drilling, FFP-B vs. SR+GS-drilling, FFP-B vs. NE-broadcast, FFP-B vs. NE-drilling, FFP-B vs. NE+GS-drilling) showed a large influence of nutrient management on $\mathrm{N}$-factor productivity but it was found non-significant in wheat crop in 2014-2015 although it was found significant with Broadcast vs. Drilling, FFP vs. SSNM, and FFP-B vs. NE-drilling in 2015-16. In case of maize, it was found non-significant with FFP-broadcast (B) vs. SR-broadcast in both years (Table S1).

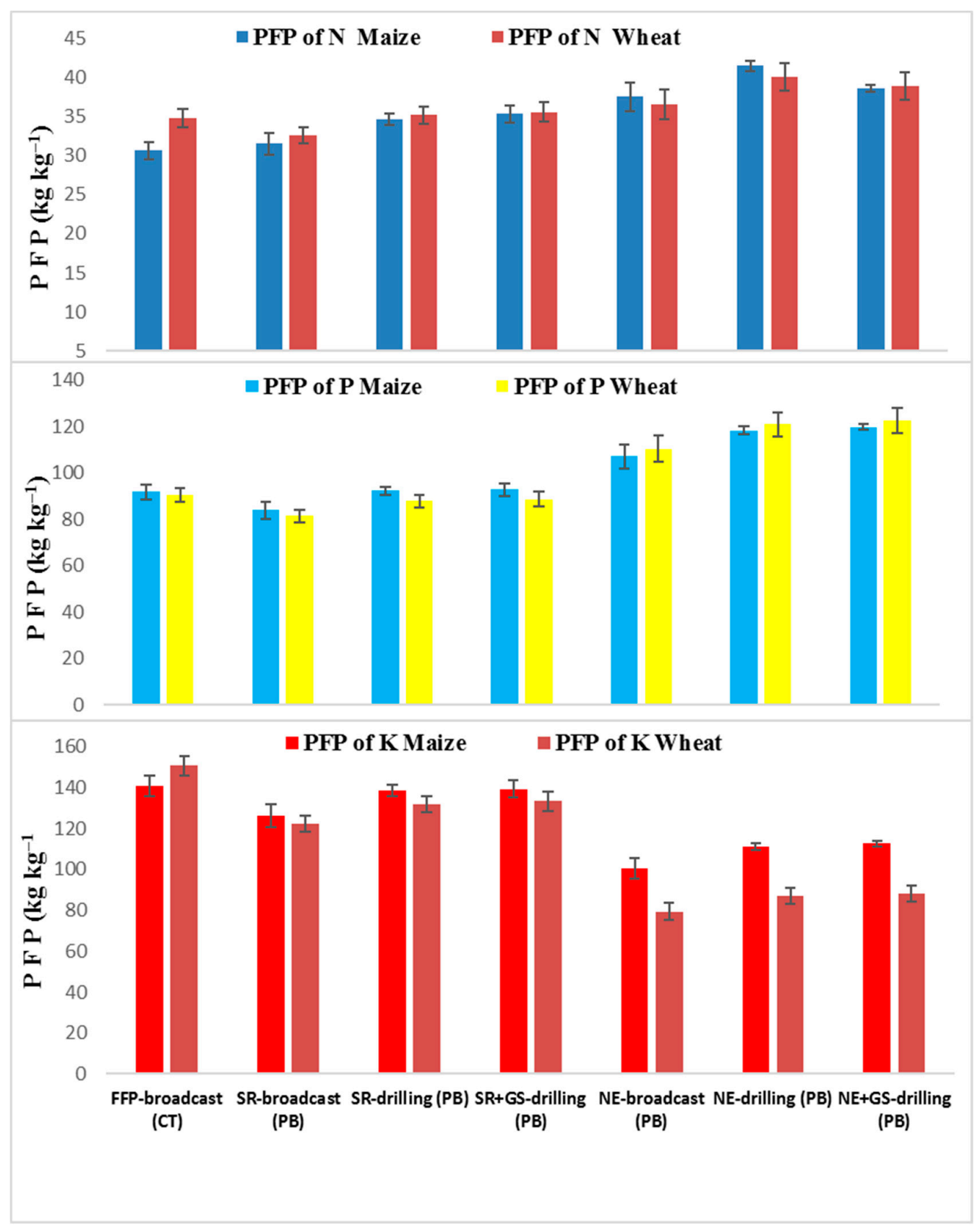

Figure 5. Partial factor productivity (PFP) of applied nitrogen, phosphorus and potassium as affected by different nutrient management strategies under maize-wheat system. Refer Table 2 for details of nutrient management treatments. Vertical bar shows standard error of the mean.

\subsection{Carbon Budgeting and Carbon Sustainability Index (CSI)}

The cumulative C-input, output, and CSI computed for the MW system were considerably altered by tillage, residue, and different nutrient management strategies (Table 5). 
Inputs for production such as synthetic fertilizer (NPK), diesel, labor, tillage, machinery, and other pesticides, etc., were associated with $\mathrm{C}$-inputs. The minimum $\mathrm{C}$-input on a maize-wheat system basis was estimated under NE+GS-drilling (PB) with $710 \mathrm{MJ} \mathrm{ha}^{-1}$ in 2014-2015 and SR-drilling (PB) with $722 \mathrm{MJ} \mathrm{ha}^{-1}$ during 2015-2016, while minimum under FFP-broadcast (CT) (651.57 MJ ha ${ }^{-1}$ and $652 \mathrm{MJ} \mathrm{ha}^{-1}$ ) (Table 5). The maximum Coutput on a maize-wheat system basis was recorded under NE+GS-drilling (PB) $(13,112$ and $\left.13,234 \mathrm{MJ} \mathrm{ha}^{-1}\right)$, while minimum under FFP-broadcast (CT) (10559 and 10,788 $\mathrm{MJ} \mathrm{ha}^{-1}$ ) in 2014-15 and 2015-2016, respectively (Table 5). Under NE+GS-drilling (PB), the C-output was recorded $3-12 \%$ (Average of $2 \mathrm{yrs}^{\prime}$ ) higher as compared to other treatments. The highest CSI in MW system was 36.14 and 37.27 under NE-drilling (PB) during 2014-2015 and 2015-2016, respectively. The minimum CSI was observed under FFP-broadcast (CT) (31.05 and 31.56) over the experimental years. NE-drilling (PB), produced $13 \%$ and $10 \%$ more CSI, respectively as compared to treatments FFP-broadcast (CT) and SR-broadcast (PB) (Table 5). The contrast (Broadcast vs. Drilling, FFP vs. SSNM, FFP-broadcast (B) vs. SRbroadcast, FFP-B vs. SR-drilling, FFP-B vs. SR+GS-drilling, FFP-B vs. NE-broadcast, FFP-B vs. NE-drilling, FFP-B vs. NE+GS-drilling) showed an influence of nutrient management on CSI. In wheat crop, contrast study found non-significant with Broadcast vs. Drilling, FFP-broadcast (B) vs. SR-broadcast, FFP-B vs. SR-drilling, FFP-B vs. SR+GS-drilling and FFP-B vs. NE+GS-drilling in 2014-2015 and in 2015-2016 it was found with FFP-broadcast (B) vs. SR-broadcast, FFP-B vs. SR-drilling, and FFP-B vs. NE+GS-drilling. In case of maize crop, Broadcast vs. Drilling, FFP-broadcast (B) vs. SR-broadcast, FFP-B vs. SR-drilling, and FFP-B vs. SR+GS-drilling were non-significant in 2014-2015. In 2015-2016 it was found non-significant with FFP-broadcast (B) vs. SR-broadcast, FFP-B vs. SR-drilling, and FFP-B vs. SR+GS-drilling (Table S1).

Table 5. Effects of different nutrient management strategies on carbon sustainability index (CSI) during 2014-2015 and 2015-2016 in maize-wheat system.

\begin{tabular}{|c|c|c|c|c|c|c|c|c|c|}
\hline \multirow[t]{2}{*}{ Treatments $^{a}$} & \multicolumn{3}{|c|}{ Total C Input(MJ ha-1) } & \multicolumn{3}{|c|}{ Total C Output(MJ ha $\left.{ }^{-1}\right)$} & \multicolumn{3}{|c|}{ Sustainability Index } \\
\hline & Maize & Wheat & System & Maize & Wheat & System & Maize & Wheat & System \\
\hline \multicolumn{10}{|l|}{ 2014-2015 } \\
\hline FFP-broadcast (CT) & $284^{\mathrm{Gb}}$ & $366^{\mathrm{D}}$ & $651^{\mathrm{F}}$ & $5427^{\mathrm{D}}$ & $5132^{C}$ & $10559^{\mathrm{E}}$ & $18.07^{\mathrm{C}}$ & $12.99^{\mathrm{D}}$ & $31.05^{\mathrm{C}}$ \\
\hline SR-broadcast (PB) & $322^{D}$ & $367^{\mathrm{D}}$ & $689^{C}$ & $6139^{C}$ & $5516^{\mathrm{BC}}$ & $11655^{\mathrm{D}}$ & $18.07^{C}$ & $14.02 \mathrm{CD}$ & $32.09^{B C}$ \\
\hline SR-drilling (PB) & $338^{A}$ & $383^{B}$ & $722^{A}$ & $6587^{\text {B }}$ & $5786^{\mathrm{AB}}$ & $12374^{B C}$ & $18.46^{\mathrm{C}}$ & $14.07^{\mathrm{C}}$ & $32.53^{\mathrm{BC}}$ \\
\hline SR+GS-drilling (PB) & $336^{\mathrm{B}}$ & $386^{\mathrm{A}}$ & $722^{A}$ & $6671^{\mathrm{AB}}$ & $5836^{\mathrm{AB}}$ & $12507^{\mathrm{ABC}}$ & $18.83^{\mathrm{BC}}$ & $14.12^{\mathrm{BC}}$ & $32.94^{\mathrm{B}}$ \\
\hline NE-broadcast (PB) & $303^{F}$ & $349^{\mathrm{F}}$ & $652^{\mathrm{E}}$ & $6516^{\mathrm{BC}}$ & $5719 \mathrm{AB}$ & $12236 \mathrm{CD}$ & $20.45^{\mathrm{A}}$ & $15.39^{\mathrm{A}}$ & $35.84^{\mathrm{A}}$ \\
\hline NE-drilling (PB) & $320^{\mathrm{E}}$ & $366^{\mathrm{E}}$ & $686^{\mathrm{D}}$ & $7003^{A}$ & $5952^{\mathrm{A}}$ & $12956^{\mathrm{AB}}$ & $20.88^{\mathrm{A}}$ & $15.26^{\mathrm{A}}$ & $36.14^{\mathrm{A}}$ \\
\hline $\mathrm{NE}+\mathrm{GS}$-drilling (PB) & $335^{C}$ & $374^{C}$ & $710^{\mathrm{B}}$ & $7052^{\mathrm{A}}$ & $6059^{A}$ & $13112^{\mathrm{A}}$ & $20.03 \mathrm{AB}$ & $15.17^{\mathrm{AB}}$ & $35.20^{\mathrm{A}}$ \\
\hline \multicolumn{10}{|l|}{ 2015-2016 } \\
\hline FFP-broadcast (CT) & $284^{\mathrm{G}}$ & $367^{\mathrm{D}}$ & $652^{\mathrm{F}}$ & $5315^{\mathrm{D}}$ & $5472^{C}$ & $10788^{C}$ & $17.67^{\mathrm{B}}$ & 13.89 & $31.56^{\mathrm{C}}$ \\
\hline SR-broadcast (PB) & $321^{\mathrm{D}}$ & $367^{\mathrm{E}}$ & $688^{\mathrm{D}}$ & $6143^{C}$ & $5599^{B C}$ & $11742^{\mathrm{B}}$ & $18.12^{\mathrm{B}}$ & 14.25 & $32.37^{\mathrm{BC}}$ \\
\hline SR-drilling (PB) & $338^{\mathrm{A}}$ & $384^{\mathrm{A}}$ & $722^{A}$ & $6626^{\mathrm{B}}$ & $6132^{\mathrm{A}}$ & $12758^{\mathrm{A}}$ & $18.59^{\mathrm{B}}$ & 14.96 & $33.55^{\mathrm{B}}$ \\
\hline SR+GS-drilling $(\mathrm{PB})$ & $334^{\mathrm{B}}$ & $381^{\mathrm{B}}$ & $715^{\mathrm{B}}$ & $6675^{\mathrm{AB}}$ & $6167^{\mathrm{A}}$ & $12843^{\mathrm{A}}$ & $18.97^{\text {B }}$ & 15.16 & $34.13^{B}$ \\
\hline NE-broadcast (PB) & $293^{F}$ & $348^{\mathrm{G}}$ & $642^{\mathrm{G}}$ & 6509 BC & $5615^{\mathrm{BC}}$ & $12125^{\mathrm{B}}$ & $21.14^{\mathrm{A}}$ & 15.12 & $36.26^{\mathrm{A}}$ \\
\hline NE-drilling (PB) & $310^{\mathrm{E}}$ & $365^{\mathrm{F}}$ & $676^{\mathrm{E}}$ & $7085^{\mathrm{A}}$ & $6016^{\mathrm{AB}}$ & $13101^{\mathrm{A}}$ & $21.80^{\mathrm{A}}$ & 15.47 & $37.27^{\mathrm{A}}$ \\
\hline NE+GS-drilling (PB) & $329^{C}$ & $372^{C}$ & $701^{C}$ & $7114^{\mathrm{A}}$ & $6119^{A}$ & $13234^{\mathrm{A}}$ & $20.62^{A}$ & 15.41 & $36.03^{A}$ \\
\hline
\end{tabular}

${ }^{a}$ Refer Table 2 for details of nutrient management treatments. ${ }^{b}$ Means within different nutrient management strategies by different letters are significantly different from one another based on LSD 0.05 .

\subsection{Global Warming Potential (GWP)}

Total GHG emission in terms of GWP along with GHG intensity of maize, wheat, and MW system considerably varied between the different methods of tillage and also with the diverse nutrient management approaches in both the years (Figure 6). In maize, the highest total GHG emission (Average of 2 years) $\left(758.54 \mathrm{~kg} \mathrm{CO}_{2}\right.$ eq. ha ${ }^{-1}$ ) was recorded under the farmer's fertilizer management practices $\{$ FFP-broadcast $(\mathrm{CT})\}$ and lowest (-911.24 $\mathrm{kg} \mathrm{CO}_{2}$ eq. ha ${ }^{-1}$ ) under Nutrient Expert with drilling \{NE-drilling (PB)\}) 
method of fertilizer application. Similarly, the highest emission intensity was also recorded under FFP-broadcast (CT) (180.29 $\mathrm{kg} \mathrm{CO}_{2}$-eq $\mathrm{Mg}^{-1}$ maize) and lowest with NE-broadcast (PB) $\left(-159.35 \mathrm{~kg} \mathrm{CO}_{2}\right.$-eq $\mathrm{Mg}^{-1}$ maize) and NE-drilling (PB) $\left(-153.98 \mathrm{~kg} \mathrm{CO}_{2}\right.$-eq $\mathrm{Mg}^{-1}$ maize). In wheat, highest (Average of 2 years) total GHG emission $\left(\mathrm{CO}_{2}\right.$ eq. ha $\left.{ }^{-1}\right)$ and emission intensity ( $\mathrm{kg} \mathrm{CO}_{2}$-eq $\mathrm{Mg}^{-1}$ wheat) was recorded under FFP-broadcast (CT) (908.63 $\mathrm{kg} \mathrm{CO}_{2}$ eq. ha ${ }^{-1}$ and $197.65 \mathrm{~kg} \mathrm{CO}_{2}$-eq $\mathrm{Mg}^{-1}$ wheat) and lowest under NE-drilling (PB) (127.02 $\mathrm{kg} \mathrm{CO}_{2}$ eq. ha ${ }^{-1}$ and $22.51 \mathrm{~kg} \mathrm{CO}_{2}$-eq $\mathrm{Mg}^{-1}$ wheat). Similar trends were observed in total GHG emission as well as emission intensity at the MW system level (Figure 6). The linear contrast (Broadcast vs. Drilling, FFP vs. SSNM, FFP-broadcast (B) vs. SR-broadcast, FFP-B vs. SR-drilling, FFP-B vs. SR+GS-drilling, FFP-B vs. NE-broadcast, FFP-B vs. NE-drilling, FFP-B vs. NE+GS-drilling) showed significant influence of GWP by various management practices in both the years. The results of contrast also showed significant lower GHGs emission under NE+GS-drilling compared to FFP-broadcast and SR- broadcast treatments in both the years (Table S1).

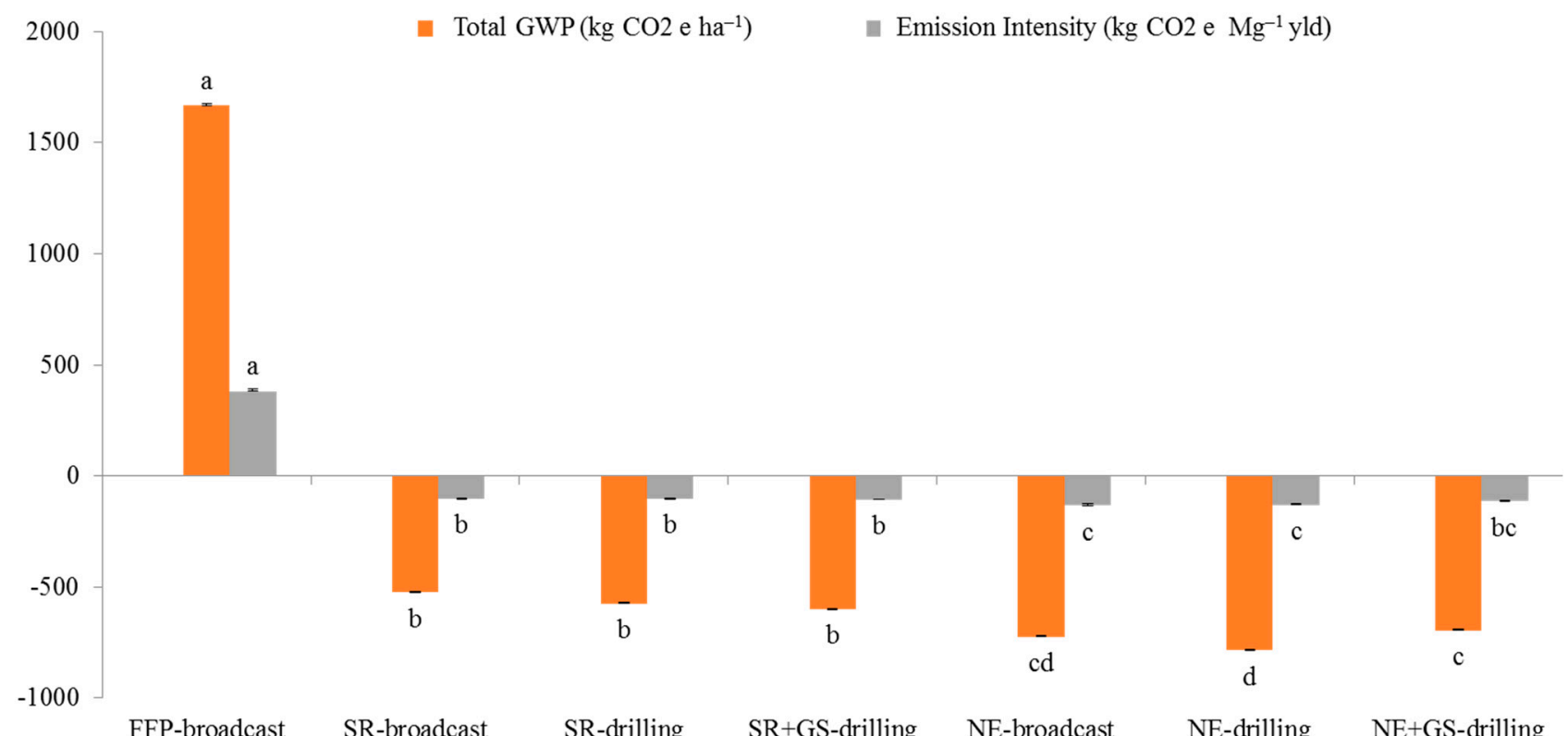

Figure 6. Global warming potential (GWP) and greenhouse gases intensity (GHGI) of maize-wheat system under different fertilizer management strategies. Vertical bar shows standard error of the mean. Refer Table 2 for details of nutrient management treatments. Values with different lower case $(a-d)$ letters are significantly different between each nutrient management treatments at LSD 0.05 .

\subsection{Correlation Coefficient ( $r$ ) Matrix}

The relationship between the four variables (grain yield, net return, $\mathrm{N}$-factor productivity, and global warming potential (GWP)) was examined using correlation coefficient matrix. The results showed that the GWP was correlated (positively or negatively) with $\mathrm{N}$-factor productivity, grain yield, and net return (Table 6). Other variables grain yield, $\mathrm{N}$ factor productivity, and net return were found to be positively correlated to each other in both the years (Table 6). In 2014-2015, grain yield was positively correlated with net return $(\mathrm{r}=0.99, p<0.05)$, PFP of $\mathrm{N}(\mathrm{r}=0.78, p<0.05)$ in MW system, where as it was negatively correlated with GWP $(\mathrm{r}=-0.85, p<0.05)$. In the year of 2015-2016 grain yield found highly positive correlation with net return $(\mathrm{r}=0.99, p<0.05)$, PFP of $\mathrm{N}(\mathrm{r}=0.80, p<0.05)$, and negatively correlated with GWP $(r=0.89, p<0.05)$ in maize wheat system. 
Table 6. Correlation coefficient (r) matrix of different grain yield, net return, partial factor productivity of nitrogen (N) and global warming potential parameters.

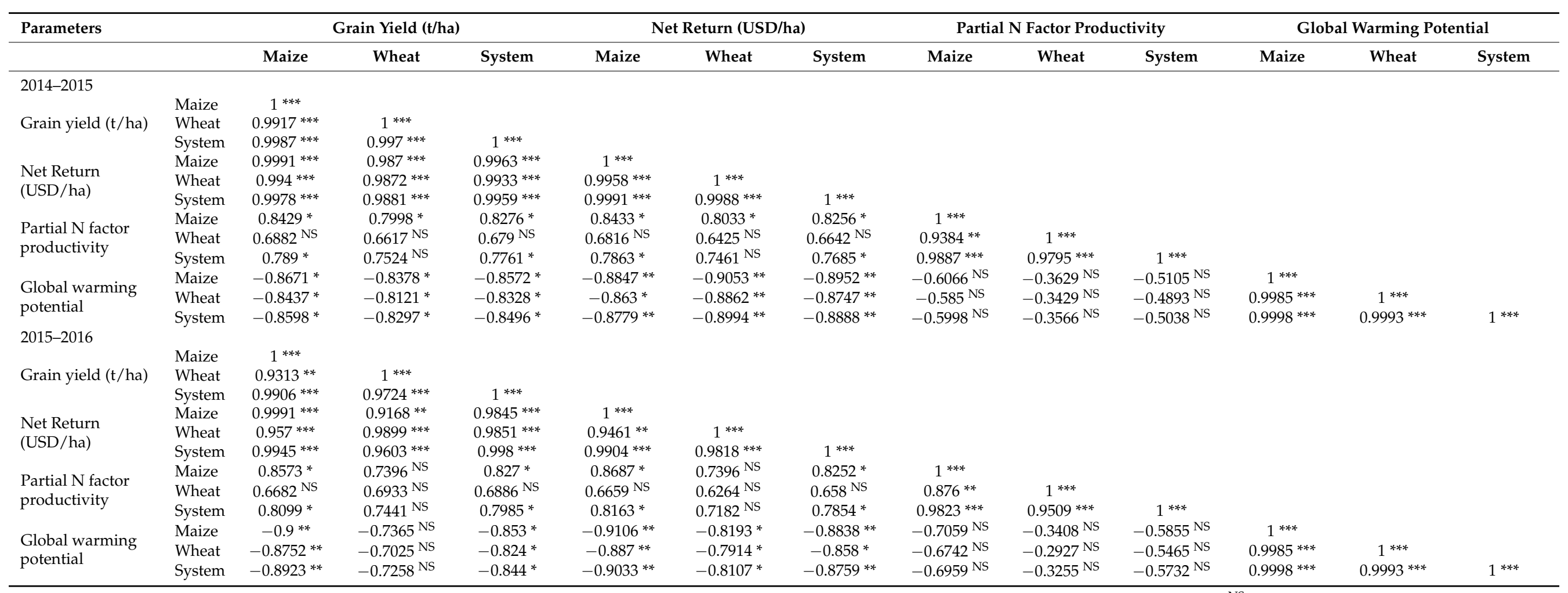

Stars indicating different level of significance; ${ }^{* * *}=$ significance level at $p<0.001 ;{ }^{* *}=$ significance level at $p<0.01 ;{ }^{*}=$ significance level at $p<0.05$; ${ }^{\text {NS }}=$ non-significant. 


\section{Discussion}

\subsection{Crop Productivity and Profitability}

PB-based maize and with various precision nutrient rates and application methods increased crop productivity related to CT with farmer fertilizer practice in both the years. The higher yield of maize ( $36.7 \%$ to $47.24 \%$ ) in the PB system with Nutrient Expert (NE)based fertilizer management related to CT system with FFP might be because of the combined effect of improved soil physical health due to residue retention in the field, appropriate nutrient dose and application methods together with better water regimes. As the study area is located in high rainfall zone, PB technology is advantageous under extreme soil moisture conditions due to better infiltration rates as well as the furrows facilitate drainage of excess water. Maize is very sensitive to excess soil moisture, hence permanent beds offer the advantage of better aeration to the root system. The different component of precision nutrient management such as drilling, drilling $+\mathrm{NE}$, drilling + $\mathrm{NE}+\mathrm{GS}$, and drilling + NE + GS + tillage increased the productivity of the maize-wheat system (2 years mean) by $9,14,16$, and 31\%, respectively, over the FFP (CT) (Table 4). Parihar et al. [20] reported significantly higher biomass productivity, net income, and NUE in ZT- and PB-based maize-wheat system in NW India than in conventional system, which is in agreement with our study. Higher infiltration rate and plant available water in no-tillage (NT) system increase water productivity compared to conventional tillage system [8]. No-till/permanent beds coupled with residue mulch and site specific nutrient management provide favorable soil moisture, better soil nutrient, water, and temperature interactions for good crop growth and contributed to higher crop productivity and nutrientuse efficiency [8,21-24].

Biological yields of MW system were higher with the drilling of NE-based nutrient management over FFP. This was probably due to better synchrony of the nutrient demand and supply. NE-based nutrient management strategy is based on crop requirement, complements with nutrient supplying capacity of the field, and therefore performs better than FP and SR for maize $[14,25]$. The results are in close conformity of the study of YadvinderSingh et al. [24], who reported that drilling of $50-75 \%$ recommended dose fertilizers (RDF) of $\mathrm{N}$ contributed to higher wheat crop productivity under the R-W cropping sequence. Similarly, Sidhu et al. [10] advocated about the surface application of fertilizers under CA leading to more loss of nutrient thereby reducing crop yield and increasing environmental pollution. Kumar et al. [26] found that drilling fertilizers encourages deeper root system where crops efficiently use nutrients available in the deeper layer which reduce the leaching losses thereby improving NUE of the crops resulting in yield increase. Bijay-Singh et al. [12] reported that GreenSeeker-based precision nutrient application method saves nitrogen in comparison to blanket RDF while keeping similar crop yields in wheat crops compared to FFP. Sapkota et al. [3] and Kakraliya et al. [5] reported that Nutrient Expert (NE) and GreenSeeker (GS) based on fertilizer application in wheat increased the crop yield, net return, and the reduced environmental footprint of production compared to farmer's fertilizer practice and state recommendation. Scharf et al. [27] and Ma et al. [28] reported that GS sensor-based nitrogen rate applied as side dressings, increased profitability and productivity while reducing $\mathrm{N}$ use and improving NUE efficiency in maize crop.

Higher crop yields, lower cost of cultivation, and efficient use of fertilizers contributed to higher net returns in our study under PB system with the drilling of fertilizers at different rates compared to FFP-broadcast (CT). The production cost was lower in the PB system as a result of minimum tillage and other input costs like irrigation, fertilizers, and labor. Various components of management i.e., drilling, drilling + NE, drilling + NE + GS, and drilling + NE + GS + tillage increased the net returns of maize-wheat system (2 years mean) by $11,19,21$, and $50 \%$, respectively, over the FFP-broadcast (CT) (Figure 4). Similarly, lower cost of production and higher net return were reported with $\mathrm{PB}$ compared to $\mathrm{CT}$ in MW and rice-wheat production system in a similar production environment $[1,29]$. Higher crop yields under Nutrient Expert-based drilling contributed to more economic returns in MW cropping pattern as a result of balanced use of nutrients at the right time [14], right place, 
and minimum losses leading to higher NUE $[6,20]$. The higher crop productivity under CA based treatments ( $\mathrm{PB}$, crop residue retention) might be due to the compound effects of better crop establishment method, better water regimes, less biotic and abiotic stress, active soil aeration, improved soil physical health, and improved nutrient use efficiency compared to FFP-broadcast $[1,7]$. The precision rate and application methods of nutrients (sub surface application) decrease nutrient losses which is improving nutrient use efficiency resulted in improve crop productivity [14].

\subsection{Nutrient-Use Efficiency}

CA based treatments increased factor productivity of $\mathrm{N}$ and $\mathrm{P}$ by $\sim 19$ and $12 \%$, respectively in maize crop compared to FFP-broadcast. However, CA based treatments decreased factor productivity of K by $\sim 14 \%$ compared to FFP-broadcast. In wheat, CA based treatments increased factor productivity of $\mathrm{N}$ and $\mathrm{P}$ by $\sim 5$ and $13 \%$, respectively in maize crop compared to FFP-broadcast. However, CA based treatments decreased factor productivity of $\mathrm{K}$ by $\sim 22 \%$ compared to FFP-broadcast. Improvement in N, P, and K (Figure 5) fertilizers-use efficiency under PB drilling than in PB and CT broadcasting could primarily be attributed to better moisture conservation and reduced losses under $\mathrm{PB}$ drilling which may help in improving plant nutrients uptake. Sapkota et al. [3] advocated that the soil covers with residue under a no-tillage system with residue retention, reduce water losses through evaporation thus conserving moisture which boosts higher growth rate of crops resulting in improved nutrient uptake rates. In our study, NE-based recommendations with drilling recorded better efficiency of nutrients than in state recommendation and FFP indicating that SSNM-based nutrient application rate, right placement, and proper timing of nutrient application when needed reduced $\mathrm{N}$ and $\mathrm{P}$ losses and improved nutrient-use efficiencies. Drilling fertilizer probably ensured the placement of fertilizer near the root zone thereby enhancing the uptake of those nutrients. The placement of N, P, and K fertilizers near the root zone increases availability of nutrients to crops at an early growing period hence enhancing the nutrient-use efficiency and resulting in higher yield gains [10]. Similarly, Hobbs and Gupta [30] reported that proper placement of fertilizer with the help of seed drill improved NUE by $10-15 \%$ as compared to traditional farmers broadcasting method of application in the rice-wheat system.

\subsection{Carbon Budgeting and Carbon Sustainability Index (CSI)}

The total carbon-input, output, and sustainability index computed for MW system were significantly influenced by tillage, residue, and different nutrient management methods (Table 5). The influence of C-inputs mainly associated with the various input resources (fertilizer (NPK), diesel, tillage, labor, lubricants, machinery and agro-chemical, etc.) used for the production of crops [17]. The low C-input was recorded under conventional tillage farmers' fertilizer practices during both the years indicating that farmers use low input which led to low productivity. The high input in PB with different fertilizer management strategies were mainly due to the additional input used like drilling and fertilizing. CA with SSNM recorded higher C-output and CSI in comparison to other treatments. This may be due to the balanced use of fertilizer which resulted in higher yield due to higher C-output and CSI. Adoption of CA-based practices with site-specific nutrient management lead to higher CSI, and CE reflecting the ability to sequester more carbon than CT and resulting in more sustainable cropping system [31,32].

\subsection{GHG Mitigation Potential}

In our study maximum $1667 \mathrm{~kg} \mathrm{CO}^{2} \mathrm{eq} / \mathrm{ha}\left(\mathrm{CO}^{2} 1657 \mathrm{~kg} \mathrm{CO}\right.$ eq $/ \mathrm{ha}, \mathrm{N} 2 \mathrm{O} 91 \mathrm{~kg} \mathrm{CO}$ eq $/ \mathrm{ha}$ and $\mathrm{CH} 40 \mathrm{~kg} \mathrm{CO}{ }^{2} \mathrm{eq} / \mathrm{ha}$ ) GWP in MW system was recorded in a conventional tillage system with a broadcast application of fertilizer $\mathrm{N}$, and the lowest was recorded under $\mathrm{PB}$ system with SSNM coupled with the drilling of fertilizer $\left(-694 \mathrm{~kg} \mathrm{CO}^{2}\right.$ eq/ha (Table S2).) (Figure 6) which indicates that the main sources of emissions were energy use in field preparation and planting. Fertilizer-induced field emission, emission from fertilizer produc- 
tion, transportation, and other management-related emissions were not different among the treatments. The negative GWP under PB systems was mainly due to carbon sequestration resulting from residue retention in the PB system whereas that was not the case in the CT system. Lower GWP was seen under NT with NE and SR nutrient management strategies with drilling method fertilizer application caused in maximum sequestration of $\mathrm{CO}_{2}$ compared to the CT farmer's fertilizer method. CT system with the broadcasting of fertilizer (FP) application methods contributed the highest $\mathrm{CO}_{2}$ emission per $\mathrm{Mg}$ of maize and wheat yield coupled with lower yield as compared to other nutrient management strategies (Figure 6). Lower total GWP combined with higher yield in PB systems than in CT systems resulted in lower emission intensity in the PB system than in the CT system (Figure 6). In the long term, no tillage system sequestered maximum $C$ (up to $0.61 \mathrm{Mg} \mathrm{C} \mathrm{ha}^{-1}$ year $^{-1}$ ) [33], which is returned into the soil [34,35] due to change in C stock as a result of crop yield and residue retention. In the region, farmers removed maize crop residues from the fields and are primarily using them as livestock feed (as greenfodder) and as fuels in their natural state with limited pre-treatment such as drying and cutting. Removing maize residue from fields and using them as household fuel contribute to GHGs emissions resulting in high GWP in CT farmers practices compared to CA-based practices. Even at government extension, present understanding of the rational use of crop residues for livestock and soil amendment is incomplete, partial, and primarily based on anecdotal evidence with limited systematic assessments.

In PB planting technology, the emission of $\mathrm{CO}_{2}$ per $\mathrm{Mg}$ of maize and wheat yield is found lower compared to NE and SR-based drilling, which might be due to increased yield with these nutrient application methods compared to broadcast application of $\mathrm{N}$ which is prone to more losses. Drilling of fertilizer $\mathrm{N}$ confirmed improved use and uptake of nutrients by the crops and thereby reducing the losses. Highest GWP was recorded in farmers' fertilizer application methods than other nutrient application methods showing the importance of efficient management of nutrients not only to increase crops yield but also to shrink in the global warming potential of the maize-wheat system. The higher quantity of $\mathrm{K}$ fertilizer used in NE-based system probably helps to increase the uptake of other nutrients by crops, thereby producing more yield which is results in lower emission intensity compared to other nutrient management strategy. Sapkota et al. [3] also reported that precision application of nutrients based on Nutrient Expert tools increased crop productivity, profitability, and fertilizer-use and nutrient-use efficacy, while reducing GHG emission as compared to state recommendation and farmers' fertilization practice in NW India. Our results indicate that NE-guided drilling method of fertilizer application together with the GS-based nutrient application method can make maize-wheat system a sink of carbon under CA (PB with residue retention) system. However, despite the economic and environmental benefits of precision nutrient management, CA practices are yet to be widely adopted by the farmers in the IGP region. This is mainly because of lack of scaleappropriate and locally adapted machineries, incomplete understanding of rational use of crop residues by farmers, and traditional mindset on crop establishment and management practices. Further, farmers' investment decisions are mainly influenced by their socioeconomic characteristics, for instance, investment capacity, knowledge on CA practices and technologies, and access to markets. These CA-based nutrient management strategies can be recommended as package/portfolio of practices in the region for improvement in crop productivity, nutrient, and carbon efficiency, and economically viable with decreasing emissions of GHGs.

\subsection{Correlation Matrix}

Significant positive correlations among grain yield, net return, and partial factor productivity of $\mathrm{N}$ were observed in both the years (Table 6). In 2014-2015, grain yield was positively correlated with net return $(\mathrm{r}=0.99, p<0.05)$, PFP of $\mathrm{N}(\mathrm{r}=0.78, p<0.05)$ in MW system where as it was negatively correlated with GWP $(\mathrm{r}=-0.85, p<0.05)$. In the year of 2015-2016 grain yield found highly positive correlation with net return $(r=0.99, p<0.05)$, 
PFP of $\mathrm{N}(\mathrm{r}=0.80, p<0.05)$ and negatively correlated with GWP $(\mathrm{r}=0.89, p<0.05)$ in maize-wheat system. The strong correlation between grain yield ant net return might be due to the adoption of CA-based maize-wheat system which reduces the cost of inputs and increases production. The negative correlation between grain yield, net return, PFP of $\mathrm{N}$ with GWP showed that CA-based practices and precision rate and placement of nutrients minimize GHGs emissions resulted in low GWP. Higher carbon input in the soil through recycling of huge quantities of crop residues coupled with ZT resulted in the formation of higher soil organic carbon (SOC) in CA-based scenarios which is highly correlated with residue recycling [6]. This strong correlation may be due to the fact that benefits of proper management of nutrients (right dose, right placement) in soil are significant and improve C-sequestration and soil health [5].

\section{Conclusions}

Traditional fertilizer application and crop establishment methods have a significant and downside effect on agricultural and environmental sustainability in the region, as these practices use excessive and imbalanced $\mathrm{N}$ fertilizers and intensive tillage operations. In this context, precision application of nutrients at right amount with right placement in conservation agriculture-based maize-wheat system complements the benefits of CA toward sustainability issues. Use of Nutrient Expert and Green Seeker guided nutrient recommendations coupled with precise drilling of fertilizers in PB-based maize-wheat system significantly increased the nutrient-use-efficiency, crop productivity, and profitability, yet contributing to climate change mitigation efforts too. Balanced and site-specific nutrient application improved the C-sustainability index and reduced the emission intensity as well as global warming potential. The evidence of multiple benefits from co-adoption of CA and improved nutrient management strategies over conventional fertilizer recommendations with traditional crop establishment methods although gives a momentum for large-scale adoption, the constraints like lack of scale appropriate machinery, behavioral issues of the farmers, etc., should be overcome for its faster adoption. Moreover, generating evidence for long-term impact of such production packages must be studied in multiple locations and different cropping systems to address food, nutrition, economic, and environmental problems in the region. Undoubtedly, not only such a study be continued on a longer-term basis but should be replicated in other agro-ecologies.

Supplementary Materials: The following are available online at https:/ /www.mdpi.com/article/10.3 390/agronomy11112320/s1, Table S1: Significance effect of different nutrient management strategies and their linear contrast on grain yield, net return, carbon sustainability index (CSI), partial N factor productivity (PFP of N), Table S2: Effect of management practices on major green house gasses under maize-wheat system.

Author Contributions: Conceptualization, M.L.J. and R.K.J.; methodology, D.B. and T.B.S.; software, S.K.K.; validation, R.K.J. and M.L.J.; formal analysis, M.K.; investigation, D.B.; resources, R.K.J.; data curation, D.B.; writing-original draft preparation, D.B.; writing—review and editing, R.K.J.; visualization, D.B.; supervision, M.L.J.; project administration, M.L.J.; funding acquisition, M.L.J. All authors have read and agreed to the published version of the manuscript.

Funding: This research received no external funding.

Data Availability Statement: Not applicable.

Acknowledgments: We acknowledge the financial and technical support from CGIAR Research Programs on Climate Change, Agriculture and Food Security (CCAFS), Wheat Agri-food Systems (WHEAT) and Indian Council of Agricultural Research (ICAR). Also acknowledge all donors who supported this research through their contributions to the CGIAR Fund. For a list of Fund donors please, see: http:/ / www.cgiar.org/our-funders / (accessed on 10 May 2019).

Conflicts of Interest: The authors declare no conflict of interest. 


\section{References}

1. Jat, R.K.; Sapkota, T.B.; Singh, R.G.; Jat, M.L.; Kumar, M.; Gupta, R.K. Seven years of conservation agriculture in a rice-wheat rotation of Eastern Gangetic Plains of South Asia: Yield trends and economic profitability. Field Crop Res. 2014, 164, 199-210. [CrossRef]

2. Government of Bihar. State Action Plan on Climate Change: Building Resilience through Development; Government of Bihar: Bihar, India, 2012.

3. Sapkota, T.B.; Majumdar, K.; Jat, M.L.; Kumar, A.; Bishnoi, D.K.; Mcdonald, A.J.; Pampolino, M. Precision nutrient management in conservation agriculture-based wheat production of North-west India: Profitability, nutrient use efficiency and environmental footprint. Field Crop. Res. 2014, 155, 233-244. [CrossRef]

4. Singh, V.K.; Shukla, A.K.; Singh, M.P.; Majumdar, K.; Mishra, R.P.; Rani, M.; Singh, S.K. Effect of site-specific nutrient management on yield, profit and apparent nutrient balance under pre-dominant cropping systems of Upper Gangetic Plains. Indian J. Agric. Sci. 2015, 85, 335-343.

5. Kakraliya, S.K.; Jat, H.S.; Singh, I.; Sapkota, T.B.; Singh, L.K.; Sutaliya, J.M.; Sharma, P.C.; Jat, R.K.; Lopez-Ridaura, S.; Jat, M.L. Performance of portfolios of climate smart agriculture practices in a rice-wheat system of western Indo-Gangetic plains. Agric. Water Manag. 2018, 202, 122-133. [CrossRef]

6. Jat, H.S.; Jat, R.K.; Singh, Y.; Parihar, C.M.; Jat, S.L.; Tetarwal, J.P.; Sidhu, H.S.; Jat, M.L. Nitrogen Management under Conservation Agriculture in Cereal-based Systems. Indian J. Fertil. 2016, 12, 76-91.

7. Jat, M.L.; Gathala, M.K.; Saharawat, Y.S.; Ladha, J.K.; Yadvinder, S. Conservation Agriculture in Intensive Rice-Wheat Rotation of Western Indo-Gangetic Plains: Effect on Crop Physiology, Yield, Water Productivity and Economic Profitability. Int. J. Environ. Sci. Nat. Resour. 2019, 18, 555988. [CrossRef]

8. Gathala, M.K.; Ladha, J.K.; Saharawat, Y.S.; Kumar, V.; Kumar, V.; Sharma, P.K. Effect of tillage and crop establishment methods on physical properties of a medium textured soil under a seven-year rice-wheat rotation. Soil Sci. Soc. Am. J. 2011, 75, 1851-1862. [CrossRef]

9. Jat, H.S.; Datta, A.; Choudhary, M.; Yadav, A.K.; Choudhary, V.; Sharma, P.C.; Gathala, M.K.; Jat, M.L.; McDonald, A. Effects of tillage, crop establishment and diversification on soil organic carbon, aggregation, aggregate associated carbon and productivity in cereal systems of semi-arid Northwest India. Soil Tillage Res. 2019, 190, 128-138. [CrossRef] [PubMed]

10. Sidhu, H.S.; Singh, M.; Singh, Y.; Blackwell, J.; Lohan, S.K.; Humphreys, E.; Jat, M.L.; Singh, V.; Singh, S. Development and evaluation of the Turbo Happy Seeder for sowing wheat into heavy rice residues in NW India. Field Crop. Res. 2015, 184, 201-212. [CrossRef]

11. Kakraliya, S.K.; Jat, H.S.; Singh, I.; Jat, M.L. Effect of Climate Smart Agriculture Practices on Crop yields and Factor Productivity of Rice-Wheat Cropping System in Indo-Gangetic Plains of India. Indian J. Fertil. 2019, 15, 852-858.

12. Sharma, R.K.; Jat, M.L.; Martin, K.L.; Chandna, P.; Choudhary, O.P.; Gupta, R.K.; Thind, H.S.; Uppal, H.S.; Khurana, H.S.; Uppal, R.K.; et al. Assessment of the nitrogen management strategy using an optical sensor for irrigated wheat. Agron. Sustain. Dev. 2011, 31, 589-603.

13. Purba, J.; Sharma, R.K.; Jat, M.L.; Thind, H.S.; Gupta, R.K.; Chaudhary, O.P.; Chandna, P.; Khurana, H.S.; Kumar, A.; Uppal, H.S.; et al. Site specific fertilizer nitrogen management in irrigated transplanted rice (Oryza sativa) using an optical sensor. Precis. Agric. 2015, 1, 1-21.

14. Majumdar, K.; Jat, M.L.; Shahi, V.B. Effect of spatial and temporal variability in cropping seasons and tillage practices on maize yield responses in eastern India. Better Crop.-South Asia 2012, 6, 4-6.

15. Feliciano, D.; Nayak, D.; Vetter, S.; Hillier, J. CCAFS Mitigation Option Tool 2015. Available online: www.ccafs.cigar.org (accessed on 25 October 2018).

16. IPCC. Climate Change 2013: The Physical Science Basis in Contribution of Working Group I to the Fifth Assessment Report of the Intergovernmental Panel on Climate Change 2013; Stocker, T.F., Ed.; IPCC: Cambridge, UK; New York, NY, USA; pp. $710-716$.

17. Lal, R.; Kimble, J.M. Conservation tillage for carbon sequestration. Nutr. Cycl. Agroecosyst. 1997, 49, 243-253. [CrossRef]

18. Gomez, K.A.; Gomez, A.A. Statistical Procedures for Agricultural Research 1984; John Wiley \& Sons: New York, NY, USA, 1984.

19. SAS Institute. SAS/STAT User's Guide; Version 8-1; SAS Inst.: Cary, NC, USA, 2001.

20. Parihar, C.M.; Jat, S.L.; Singh, A.K.; Ghosh, A.; Rathore, N.S.; Kumar, B.; Pradhan, S.; Majumdar, K.; Satyanarayana, T.; Jat, M.L.; et al. Effects of precision conservation agriculture in a maize-wheat-mungbean rotation on crop yield, water-use and radiation conversion under a semiarid agro-ecosystem. Agric. Water Manag. 2017, 192, 306-319. [CrossRef]

21. Jat, M.L. Climate smart agriculture in intensive cereal-based systems: Scalable evidence from Indo-Gangatic Plains. In Agriculture under Climate Change: Threats, Strategies and Policies; Belavadi, V.V., Nataraja Karaba, N., Gangadharappa, N.R., Eds.; Allied Publishers Pvt Ltd.: New Delhi, India, 2017; pp. 147-154. ISBN 978-93-85926-27-2d.

22. Jat, M.L.; Gathala, M.K.; Saharawat, Y.S.; Tetarwal, J.P.; Gupta, R.; Yadvinder, S. Double no-till and permanent raised beds in maize-wheat rotation of northwestern Indo-genetic plains of India: Effects on crop yields water productivity, profitability and soil physical properties. Field Crop. Res. 2013, 149, 291-299. [CrossRef]

23. Jat, M.L.; Dagar, J.C.; Sapkota, T.B.; Singh, Y.; Govaerts, B.; Ridaura, S.L.; Saharawat, Y.S.; Sharma, R.K.; Tetarwal, J.P.; Jat, R.K.; et al. Climate change and agriculture: Adaptation strategies and mitigation opportunities for food security in South Asia and Latin America. Adv. Agron. 2016, 137, 127-236. 
24. Singh, Y.; Singh, M.; Sidhu, H.S.; Humphreys, E.; Thind, H.S.; Jat, M.L.; Blackwell, J.; Singh, V. Nitrogen management for zero till wheat with surface retention of rice residues in north-west India. Field Crop. Res. 2015, 184, 183-191.

25. Satyanarayana, T.; Majumdar, K.; Pampolino, M.; Johnston, A.M.; Jat, M.L.; Kuchanur, P.; Sreelatha, D.; Sekhar, J.C.; Kumar, Y.; Maheswaran, R. Nutrient Expert: A tool to optimise nutrient use and improve productivity of maize. Better Crop-South Asia 2012, $6,18-21$.

26. Kumar, M.; Sheoran, P.; Yadav, A. Productivity potential of wheat (Triticum aestivum) in relation to different planting methods and nitrogen management strategies. Indian J. Agric. Sci. 2010, 80, 427-429.

27. Scharf, P.C.; Shannon, D.K.; Palm, H.L.; Sudduth, K.A.; Drummond, S.T.; Kitchen, N.R.; Mueller, L.J.; Hubbard, V.C.; Oliveira, L.F. Sensor-Based Nitrogen Applications Out-Performed Producer-Chosen Rates for Corn in On-Farm Demonstrations. Agron. J. 2011, 103, 1683-1691.

28. Ma, B.; Wu, T.; Shang, J. On-farm comparison of variable rates of nitrogen with uniform application to maize on canopy reflectance, soil nitrate, and grain yield. J. Plant Nutr. 2014, 177, 216-226. [CrossRef]

29. Jat, R.D.; Jat, H.S.; Nanwal, R.K.; Yadav, A.K.; Bana, A.; Choudhary, K.M.; Kakraliya, S.K.; Sutaliya, J.M.; Sapkota, T.B.; Jat, M.L. Conservation agriculture and precision nutrient management practices in maize-wheat system: Effects on crop and water productivity and economic profitability. Field Crop. Res. 2018, 222, 111-120. [CrossRef]

30. Hobbs, P.R.; Gupta, R. Problems and challenges of no-till farming for the rice-wheat systems of the Indo-Gangetic plains in South Asia. In Sustainable Agriculture and the International Rice-Wheat System; Lal, R., Hobbs, P., Uphoff, N., Hansen, D.O., Eds.; Ohio State University: Columbus, OH, USA; Marcel Dekker: New York, NY, USA, 2004.

31. Dubey, A. Carbon Footprints of Agriculture in Ohio, USA and Punjab, India. Master's Thesis, The Ohio State University, Columbus, OH, USA, 2008; p. 128.

32. Dubey, A.; Lal, R. Carbon footprint and sustainability of Agricultural Production Systems in Punjab, India, and Ohio, USA. J. Crop Improv. 2009, 23, 332-350. [CrossRef]

33. Mazzoncini, M.; Sapkota, T.B.; Barberi, P.; Antichi, D.; Risaliti, R. Long-term effect of tillage, nitrogen fertilization and cover crops on soil organic carbon and total nitrogen content. Soil Tillage Res. 2011, 114, 165-174. [CrossRef]

34. Sapkota, T.B.; Jat, R.K.; Singh, R.G.; Jat, M.L.; Stirling, C.M.; Jat, M.K.; Bijarniya, D.; Kumar, M.; Singh, Y.; Saharawat, Y.S.; et al. Soil organic carbon changes after seven years of conservation agriculture in a rice-Wheat system of the eastern Indo-Gangetic Plains. Soil Use Manag. 2017, 33, 81-89. [CrossRef]

35. Jat, H.S.; Datta, A.; Sharma, P.C.; Kumar, V.; Yadav, A.K.; Choudhary, M.; Choudhary, V.; Gathala, M.K.; Sharma, D.K.; Jat, M.L.; et al. Assessing soil properties and nutrient availability under conservation agriculture practices in a reclaimed sodic soil in cereal-based systems of North-West India. Arch. Agron. Soil Sci. 2017, 64, 531-545. [CrossRef] 